\title{
The influence of the vertical distribution of emissions on tropospheric chemistry
}

\author{
A. Pozzer ${ }^{1,2}$, P. Jöckel ${ }^{2, *}$, and J. Van Aardenne ${ }^{3}$ \\ ${ }^{1}$ The Cyprus Institute, Energy, Environment and Water Research Centre, Nicosia, Cyprus \\ ${ }^{2}$ Max-Planck Institute of Chemistry, Air Chemistry Department, Mainz, Germany \\ ${ }^{3}$ European Commission, DG Joint Research Centre, Ispra, Italy \\ *now at: Deutsches Zentrum fuer Luft- und Raumfahrt, Oberpfaffenhofen, Wessling, Germany \\ Received: 22 June 2009 - Published in Atmos. Chem. Phys. Discuss.: 28 July 2009 \\ Revised: 26 November 2009 - Accepted: 28 November 2009 - Published: 15 December 2009
}

\begin{abstract}
The atmospheric chemistry general circulation model EMAC (ECHAM5/MESSy atmospheric chemistry) is used to investigate the effect of height dependent emissions on tropospheric chemistry. In a sensitivity simulation, anthropogenic and biomass burning emissions are released in the lowest model layer. The resulting tracer distributions are compared to those of a former simulation applying height dependent emissions. Although the differences between the two simulations in the free troposphere are small (less than $5 \%$ ), large differences are present in polluted regions at the surface, in particular for $\mathrm{NO}_{\mathrm{x}}$ (more than $100 \%$ ), $\mathrm{CO}$ (up to $30 \%$ ) and non-methane hydrocarbons (up to $30 \%$ ), whereas for $\mathrm{OH}$ the differences at the same locations are somewhat lower $(15 \%)$. Global ozone formation is virtually unaffected by the choice of the vertical distribution of emissions. Nevertheless, local ozone changes can be up to $30 \%$. Model results of both simulations are further compared to observations from field campaigns and to data from measurement stations.
\end{abstract}

\section{Introduction}

Emission data are essential for a realistic simulation of the chemistry in chemistry climate models. Accurate emission data require an appropriate spatial and temporal resolution. Although the spatial resolution is generally confined in a two-dimensional representation, the vertical distribution of the emissions is also an information which needs to be ad-

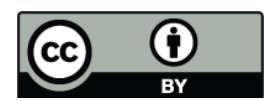

Correspondence to: A. Pozzer

(pozzer@cyi.ac.cy) dressed. This topic is well known and a plethora of case studies show the importance of a correct vertical distribution of biomass burning plume emissions for a realistic representation of tracers and aerosols (Fromm et al., 2000; Jost et al., 2004; Fromm et al., 2005; Luderer et al., 2006). For global chemistry models, a simple and computationally affordable method is to arbitrarily distribute the emissions throughout the tropospheric column (e.g. Cook et al., 2007; Pfister et al., 2005; Matichuk et al., 2007; Generoso et al., 2007) Recently, more sophisticated approaches have been used, with an online calculation of injection heights based on thermodynamics calculations (Freitas et al., 2006; Hodzic et al., 2007).

Unlike the role of biomass burning plume emissions, the importance of the vertical distribution of anthropogenic emissions for a correct tracer representation in global models is still unclear. For these kind of emissions, only a few studies or measurements of emission heights exist (see de Meij et al., 2006; Pregger and Friedrich, 2009, and references therein). Hence, three-dimensional models have to rely on simple assumptions on the height dependency of the anthropogenic emissions. Furthermore, also in the emission models, information on the vertical distribution has only very recently and/or only partly been implemented (Friedrich et al., 2000). Pregger and Friedrich (2009) showed that this is a major issue in regional/urban models. Moreover, they showed that the distribution of the emissions into different model layers is particularly important for large sources, which also play a major role in global models.

In this study two different simulations, one with emissions in the lowest model layer and one with a height dependent emission distribution are compared. After a description of the model setup, resulting differences in the distribution of the carbon monoxide (CO) and non-methane hydrocarbons

Published by Copernicus Publications on behalf of the European Geosciences Union. 
(NMHC), the reactive nitrogen family, $\left(\mathrm{NO}_{\mathrm{x}}=\mathrm{NO}+\mathrm{NO}_{2}\right.$, $\mathrm{NO}_{\mathrm{y}}=\mathrm{NO}+\mathrm{NO}_{2}+\mathrm{HNO}_{3}+\mathrm{PAN}$, peroxyacetylnitrate), the hydroxyl radical $(\mathrm{OH})$ and ozone $\left(\mathrm{O}_{3}\right)$ are analysed. Finally, results from the two simulations are compared to aircraft and station measurements. It is shown that the choice of the vertical distribution of the emissions into different model layers is essential for a correct representation of the chemistry in the planetary boundary layer in polluted regions.

\section{Model description and setup}

The ECHAM5/MESSy atmospheric chemistry (EMAC) model is a combination of the general circulation model ECHAM5 (Roeckner et al., 2006, version 5.3.01) and the Modular Earth Submodel System (Jöckel et al., 2005, MESSy; version 1.1). The description and evaluation of the model system has been published (Jöckel et al., 2006). More details about the model system can also be found at http://www.messy-interface.org, where a comprehensive description of the model is provided.

The results evaluated here are based on data from the reference simulation S1, as described by Jöckel et al. (2006). The simulation period covers almost 8 years from January 1998 to October 2005. Dry and wet deposition processes have been extensively described by Kerkweg et al. (2006a) and Tost et al. (2006), respectively. The emission procedure has been explained by Kerkweg et al. (2006b). The chemistry is calculated with the MECCA submodel (Sander et al., 2005). The applied spectral resolution of the ECHAM5 base model is T42, corresponding to a horizontal resolution of the quadratic Gaussian grid of approximately $2.8^{\circ} \times 2.8^{\circ}$. The applied vertical resolution consists of 90 levels (up to about $80 \mathrm{~km}$ ) of which about 25 are located in the troposphere.

The PBL is calculated in the model based on the work of Holtslag et al. (1990). The calculation is performed interactively following the approach of Troen and Mahrt (1986), using the Richardson number, the horizontal velocity components, the buoyancy parameters and the virtual temperature. See Holtslag and Boville (1993, Sect. 3) for a detailed and complete description of this method.

The model setup includes feedbacks between chemistry and dynamics via the radiation calculations. The model dynamics has been weakly nudged (Jeuken et al., 1996; Jöckel et al., 2006; Lelieveld et al., 2007) towards the analysis data of the ECMWF operational model (up to $100 \mathrm{hPa}$ ) in order to represent the realistic meteorology in the troposphere. This allows a direct comparison with observations. For more details on the model setup we refer to Jöckel et al. (2006). Here, we repeat briefly the setup of the emissions.

We used the anthropogenic emissions from the EDGAR database (van Aardenne et al., 2005, version 3.2 "fast-track") for the year 2000 as described by Pozzer et al. (2007).

The emissions were, depending on the emission class and species, distributed to 6 different heights $(45,140,240,400$,
600 and $800 \mathrm{~m}$ above ground). In fact, some anthropogenic activities can emit pollutants effectively at high altitudes. As example, it is generally well established that in the process of power generation (from solid, liquid and gaseous fuels) or during the combustion processes in the manufacturing industry, the emission temperature causes an updraft of the plume. This has also been confirmed by the measurements of Pregger and Friedrich (2009).

The chosen vertical distribution of the emissions is partly based on experiences from the EMEP model (Dimitroulopoulou and ApSimon, 1999; Simpson et al., 2003), applied after the analysis of some stack data from Eastern Europe. These vertically distributed emissions are based on the "effective" emissions, i.e. the effective elevation where the emissions take part. The detailed vertical distribution by emission class is listed in the electronic supplement (http://www.atmos-chem-phys.net/9/9417/2009/ acp-9-9417-2009-supplement.pdf).

It must be mentioned that the EMAC model is a hydrostatic model with a hybrid pressure coordinate system. This implies that the levels are not constant with respect to the geometric altitude and the number of levels within the first $800 \mathrm{~m}$ depends on the location and time. On average, the applied vertical resolution has 5 to 6 levels between ground and $800 \mathrm{~m}$ altitude.

The aircraft emissions are based on Schmitt and Brunner (1997). Hence, no aircraft emissions were used from the EDGAR database, and a constant factor of zero for the EDGAR F57 emission class (air transport), has been used, in order to avoid double counting (see http://www.atmos-chem-phys.net/9/9417/ 2009/acp-9-9417-2009-supplement.pdf).

Biogenic emissions, which are not on-line calculated (except for $\mathrm{NO}_{\mathrm{x}}$ ), are prescribed at the surface (lowest model layer) for all species and do not have any vertical distribution. $\mathrm{NO}_{\mathrm{x}}$ produced by lighting is distributed on different vertical levels, based on the parametrization of Price and Rind (1992).

The biomass burning contribution was added using the Global Fire Emissions Database (GFED version 1, Van der Werf et al., 2004) for the year 2000. No interannual variability is present for biomass burning. The debate is ongoing about biomass burning emission elevation. In general, the altitude depends on fire activities (flaming/smouldering) and location (boreal/tropical or others). In this work, biomass burning emissions are located exclusively at $140 \mathrm{~m}$ elevation. Colarco and Andreae (2004) suggested a much higher injection for boreal fires, while Ferguson et al. (2003) estimated a lower value for smouldering fires. In addition, Labonne et al. (2007) showed that for the majority of the global biomass burning activity, the injection occurs in the mixing layer, and direct injection into the free troposphere is a rare phenomenon. Langmann et al. (2009, and references therein) concluded that most of the fires deposit their emissions in the planetary boundary layer (PBL), and only in a few cases 

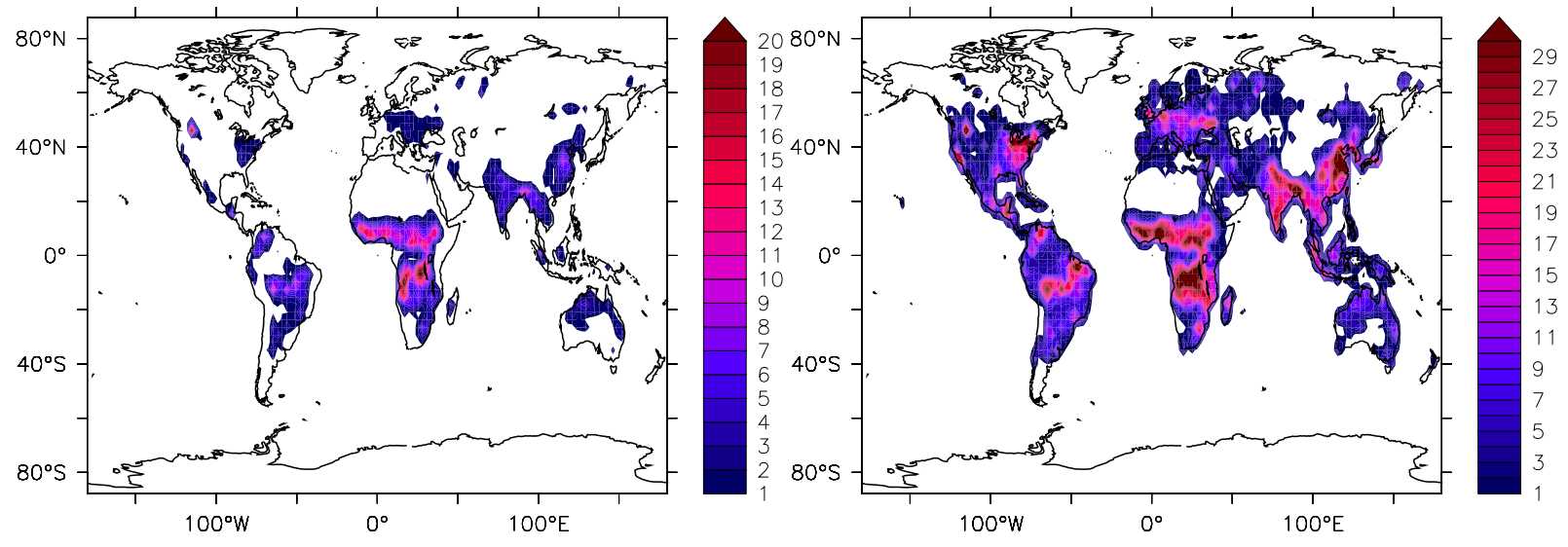

Fig. 1. Left: Annual emissions of $\mathrm{CO}$ (in $\mathrm{g} / \mathrm{m}^{2}$ ) outside the PBL. Right: Total annual emissions of $\mathrm{CO}\left(\right.$ in $\left.\mathrm{g} / \mathrm{m}^{2}\right)$.

(i.e. under specific fire and meteorological conditions), the emissions are located in the upper troposphere or even in the lower stratosphere. Based on this assumption we used a constant altitude of $140 \mathrm{~m}$ for the emissions. This implies that $\sim 67 \%$ of the biomass burning emissions are injected within the PBL, depending on the meteorological conditions. With a lower emission height, almost all biomass burning emissions will be injected into the PBL, while any higher emission height would imply a too strong injection outside the PBL. In addition, we performed test simulations (not shown) with injections at different altitudes and the best results were obtained with emissions concentrated at the chosen altitude.

In Table 1 the total emissions are summarised, including their distribution on the six vertical levels. Moreover, for the reference year 2000 the total amounts emitted above the Planetary Boundary Layer (PBL) are listed. As Table 1 shows, around $20 \%$ of the total carbon monoxide is directly emitted into the free troposphere. In Fig. 1, the geographical distribution of the $\mathrm{CO}$ emissions outside the PBL and the total emissions of $\mathrm{CO}$ is depicted. Strong sources are present in central Africa, India and partially China and the Amazonian basin, whereas in North America, Europe and Australia emissions outside the PBL are smaller.

The effect of vertically distributed emissions on the global distribution of trace species is investigated with an additional simulation, further denoted as F1. For simulation F1 we applied the same executable used in simulation S1, and the same model setup. As only difference, the namelist of the offline-emissions submodel (submodel OFFLEM, Kerkweg et al., 2006b) was altered in order to emit the species entirely in the lowest model layer, i.e. without any height dependency. This modification applies to $\mathrm{NO}, \mathrm{CO}, \mathrm{C}_{2} \mathrm{H}_{4}, \mathrm{C}_{2} \mathrm{H}_{6}$, $\mathrm{C}_{3} \mathrm{H}_{6}, \mathrm{C}_{3} \mathrm{H}_{8}, \mathrm{C}_{4} \mathrm{H}_{10}, \mathrm{CH}_{3} \mathrm{CHO}, \mathrm{CH}_{3} \mathrm{COCH}_{3}, \mathrm{CH}_{3} \mathrm{COOH}$, $\mathrm{CH}_{3} \mathrm{OH}, \mathrm{HCHO}, \mathrm{HCOOH}$ and MEK. No changes for aircraft emissions have been applied between the two simulations. The two simulations, hence, have the same aircraft emissions at the same spatio/temporal location.
Thanks to the applied nudging in both simulation S1 and simulation F1, the meteorological parameters are sufficiently similar that they are not influencing the results. To support this statement, additional tests have been performed, comparing directly the temperature and the specific humidity (two prognostic variables) between the two simulations. First, the temperature (a nudged quantity) has been compared. For a snapshot in time, the relative difference during one simulation year can reach in the troposphere up to $15 \%$, although generally the difference is less than $8 \%$. However, when the same averaging procedure used for the comparison to the aircraft campaigns (see Sect. 4.2) is applied, the differences in temperature between simulation $\mathrm{S} 1$ and simulation $\mathrm{F} 1$ are less than $0.01 \%$. Further analyses using only monthly averages at the surface show slightly larger differences (a maximum of $0.4^{\circ} \mathrm{C}$, or $0.2 \%$ all over the globe). Second, we compared the simulated specific humidity (a quantity which was not nudged). Whereas for a snapshot in time, the relative difference during one simulation year can reach up to $10-15 \%$, the monthly averages differ by $5 \%$ at maximum, but with general differences of $\leq 1 \%$. Finally, for the specific humidity averaged over the time and area of the aircraft campaigns, the differences in the tropospheric column are even smaller, about $\simeq 0.5 \%$.

Because the meteorology is comparable between simulation $\mathrm{S} 1$ and simulation F1, the on-line emissions (due to biogenic processes) and the $\mathrm{NO}+\mathrm{NO}_{2}$ produced by lightning are similar in both simulations.

For the analysis we focus on the year 2000, which is expected to be represented by the model with the highest consistency, mainly because the chosen emission database was compiled for this year. In addition, simulation S1 has already been extensively evaluated using the model output of the year 2000 (Pozzer et al., 2007). 
Table 1. Distribution of total emissions on 6 emission heights as applied in simulation $\mathrm{S} 1$, in $\mathrm{Tg}$ (tracegas)/year.

\begin{tabular}{lcccccccc}
\hline \multirow{2}{*}{ trace gas } & \multicolumn{9}{c}{ emission height in $\mathrm{m}$} & & \multirow{2}{*}{ total emission } & $\begin{array}{c}\text { emissions outside } \\
\text { the PBL }\end{array}$ \\
\hline $\mathrm{CO}$ & 45 & 140 & 240 & 400 & 600 & 800 & & 207.31 \\
$\mathrm{C}_{2} \mathrm{H}_{4}$ & 492.11 & 590.76 & 3.50 & 6.17 & 3.44 & 0.92 & 1096.90 & 2.99 \\
$\mathrm{C}_{2} \mathrm{H}_{6}$ & 18.52 & 7.51 & 0.09 & 0.16 & 0.09 & 0.02 & 26.39 & 1.80 \\
$\mathrm{C}_{3} \mathrm{H}_{6}$ & 7.59 & 4.44 & 0.13 & 0.20 & 0.11 & 0.02 & 12.49 & 1.26 \\
$\mathrm{C}_{3} \mathrm{H}_{8}$ & 6.28 & 3.51 & 0.04 & 0.07 & 0.04 & 0.01 & 9.94 & 1.15 \\
$\mathrm{C}_{4} \mathrm{H}_{10}$ & 6.48 & 1.90 & 0.18 & 0.27 & 0.13 & 0.03 & 11.99 & 5.99 \\
$\mathrm{MEK}$ & 6.05 & 5.73 & 1.29 & 1.92 & 0.94 & 0.21 & 75.17 & 2.34 \\
$\mathrm{CH}_{3} \mathrm{CHO}$ & 1.05 & 2.86 & 0.01 & 0.02 & 0.02 & 0.00 & 3.96 & 0.93 \\
$\mathrm{CH}_{3} \mathrm{COCH}$ & 45.03 & 2.74 & 0.07 & 0.11 & 0.06 & 0.01 & 48.02 & 2.52 \\
$\mathrm{CH}_{3} \mathrm{COOH}$ & 6.86 & 9.16 & 0.03 & 0.08 & 0.06 & 0.01 & 16.20 & 3.10 \\
$\mathrm{CH}_{3} \mathrm{OH}$ & 68.06 & 9.39 & 0.09 & 0.16 & 0.10 & 0.02 & 77.82 & 5.39 \\
$\mathrm{HCHO}$ & 2.67 & 4.96 & 0.04 & 0.07 & 0.04 & 0.01 & 7.79 & 1.67 \\
$\mathrm{HCOOH}^{\mathrm{a}}$ & 7.61 & 5.00 & 0.02 & 0.04 & 0.03 & 0.01 & 12.71 & 1.83 \\
$\mathrm{NO}^{\mathrm{a}}$ & 17.35 & 14.46 & 1.35 & 5.09 & 3.36 & 1.53 & 43.14 & 10.36 \\
\hline
\end{tabular}

${ }^{\mathrm{a}}$ in $\operatorname{Tg}(\mathrm{N}) /$ year. The total does not include lightning and biogenic sources which are calculated on-line $(\sim 2.1$ and $\sim 6.8 \mathrm{Tg}(\mathrm{N}) / \mathrm{year}$, respectively).

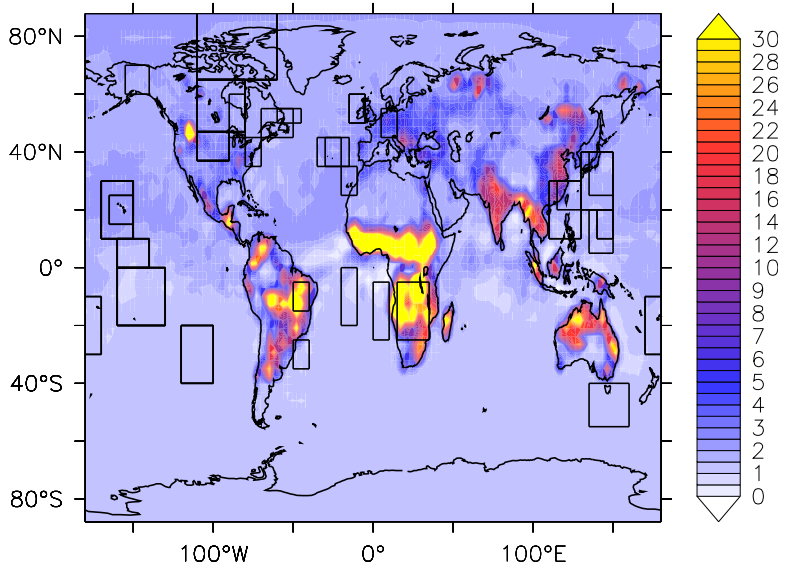

Fig. 2. Annually averaged relative differences (in \%) of CO mixing ratios between simulation $\mathrm{F} 1$ and simulation $\mathrm{S} 1((\mathrm{~F} 1-\mathrm{S} 1) / \mathrm{S} 1)$ at the surface. The overimposed boxes show the regions where the field campaigns used in this study took place.

\section{The global distribution of selected compounds}

\subsection{Carbon monoxide, $\mathrm{CO}$}

Carbon monoxide provides the most important sink for $\mathrm{OH}$ (Lelieveld et al., 2002; Logan et al., 1981; Thompson, 1992).

The CO emissions change from $492 \mathrm{Tg} /$ year at the lowest model level in simulation $\mathrm{S} 1$ to $1096 \mathrm{Tg} /$ year in simulation $\mathrm{F} 1$ (see Table 1). The differences between simulation $\mathrm{S} 1$ and simulation $\mathrm{F} 1$ for $\mathrm{CO}$ are also present for the alkanes $\left(\mathrm{C}_{2} \mathrm{H}_{6}\right.$ and $\mathrm{C}_{3} \mathrm{H}_{8}$, not shown) and the alkenes $\left(\mathrm{C}_{2} \mathrm{H}_{4}\right.$ and $\mathrm{C}_{3} \mathrm{H}_{6}$, not shown).
In simulation F1, all emissions are concentrated at the surface. The mixing ratios at the surface are therefore larger in simulation F1 than in simulation S1, despite the enhanced $\mathrm{OH}$ induced by the increased recycling of $\mathrm{OH}$ due to the higher mixing ratio of $\mathrm{NO}_{\mathrm{x}}$ (see Sects. 3.2 and 3.3).

As shown in Fig. 2, at the surface the differences in polluted regions (especially where strong biomass burning emissions occur) can be larger than $30 \%$. Also in remote regions, the mixing ratios of $\mathrm{CO}$ in simulation $\mathrm{F} 1$ are higher than in simulation S1. It must be stressed, however, that the differences for remote conditions are comparably small, only about $1-3 \%$ on annual average (see Fig. 2). In summary, at the surface simulation $\mathrm{F} 1$ shows a global increase of $\mathrm{CO}$, ranging from about $30 \%$ in polluted regions to about $3 \%$ in remote regions.

In the PBL and the free troposphere over polluted regions, simulation $\mathrm{S} 1$ shows higher mixing ratios for $\mathrm{CO}$ (up to 10 $20 \%$ ). This is restricted, however, to locations where strong emissions within the PBL are present (Central Africa, East India, Amazonia). In fact, the comparably long lifetime of $\mathrm{CO}$ allows a very effective mixing. This, in combination with the reduced $\mathrm{OH}$ abundance in simulation $\mathrm{F} 1$, causes higher mixing ratios of $\mathrm{CO}$ at almost all locations. Hence, with the exception of a few locations, $\mathrm{CO}$ is everywhere slightly (1$3 \%$ ) higher in the PBL and the free troposphere in simulation F1 compared to simulation S1.

\subsection{Reactive Nitrogen: $\mathrm{NO}_{\mathrm{x}}, \mathrm{HNO}_{3}$ and PAN}

In the troposphere the reactive nitrogen compounds play a key role in the ozone formation and in the recycling of the hydroxyl radical. While the $\mathrm{NO}_{\mathrm{x}}$ family $\left(\mathrm{NO}+\mathrm{NO}_{2}\right)$ 
Table 2. Dry deposition of nitrogen compounds in simulation $\mathrm{S} 1$ and simulation $\mathrm{F} 1$ (in $\mathrm{Tg}(\mathrm{N}) /$ year).

\begin{tabular}{|c|c|c|c|c|}
\hline \multirow[b]{2}{*}{ trace gas } & \multicolumn{2}{|c|}{ simulation $\mathrm{S} 1$} & \multicolumn{2}{|c|}{ simulation F1 } \\
\hline & $\begin{array}{c}\text { wet } \\
\text { deposition }\end{array}$ & $\begin{array}{c}\text { dry } \\
\text { deposition }\end{array}$ & $\begin{array}{c}\text { wet } \\
\text { deposition }\end{array}$ & $\begin{array}{c}\text { dry } \\
\text { deposition }\end{array}$ \\
\hline NO & - & 0.40 & - & 0.82 \\
\hline $\mathrm{NO}_{2}$ & - & 2.93 & - & 4.69 \\
\hline $\mathrm{HNO}_{3}$ & $24.35^{\mathrm{a}}$ & 13.48 & $22.53^{\mathrm{a}}$ & 13.58 \\
\hline PAN & - & 0.96 & - & 0.90 \\
\hline $\operatorname{sum}\left(\mathrm{NO}_{\mathrm{y}}\right)$ & 24.35 & 17.77 & 22.53 & 19.99 \\
\hline
\end{tabular}

a as nitrate formed from $\mathrm{HNO}_{3}$.

is important for these processes, $\mathrm{HNO}_{3}$ and PAN (peroxyacetylnitrate) are reaction products and reservoir species. $\mathrm{HNO}_{3}$ represents one of the main sinks of reactive nitrogen through its washout, and PAN represents an important $\mathrm{NO}_{\mathrm{x}}$ source in remote regions due to its temperature dependent stability. Changing the vertical distribution of the emissions by removing the height dependency, drastically increases the $\mathrm{NO}_{\mathrm{x}}$ mixing ratios at the surface (lowest model layer), with about a factor of 2 to 3 higher $\mathrm{NO}_{\mathrm{x}}$ mixing ratios in simulation F1 compared to simulation S1. This increase is compensated by a strong decrease in the PBL above the surface model layer, where simulation F1 results in 10-20\% lower mixing ratios than simulation $\mathrm{S} 1$.

As shown in Table 2, the emissions into the lowest model layer (simulation F1) result in a more efficient dry deposition of the $\mathrm{NO}_{\mathrm{x}}$ species. For the very reactive $\mathrm{NO}_{\mathrm{x}}$, the dry deposition in simulation $\mathrm{F} 1(5.5 \mathrm{Tg}(\mathrm{N})$ /year) is almost double (67\% larger) compared to the dry deposition in simulation $\mathrm{S} 1(3.3 \operatorname{Tg}(\mathrm{N}) /$ year $)$. Although this does not significantly change the global view of the $\mathrm{NO}_{\mathrm{y}}$ distribution, other compounds (e.g. $\mathrm{O}_{3}$ ) are influenced by the strong changes in the dry deposition of $\mathrm{NO}_{\mathrm{x}}$.

The global burden of PAN, which is thermally unstable, is reduced in simulation $\mathrm{F} 1$ compared to simulation $\mathrm{S} 1(\sim 5 \%)$, due to a reduced formation near the surface, where the temperature is higher than higher up in the PBL or free troposphere. This decreased burden reduces the transport into remote areas and thereby the production of $\mathrm{NO}_{\mathrm{x}}$ by thermal decomposition of PAN.

As $\mathrm{HNO}_{3}$ is mainly formed by the reaction of $\mathrm{NO}_{2}$ with $\mathrm{OH}$, it follows mainly the behavior of these two tracers (see $\mathrm{OH}$ below, Sect. 3.3). Over regions with strong $\mathrm{NO}_{\mathrm{x}}$ emissions we see an increase (up to 60\%) of $\mathrm{HNO}_{3}$ at the surface in simulation $\mathrm{F} 1$ compared to simulation $\mathrm{S} 1$, while a decrease outside the lowest layer is observed. In remote regions, instead, a small decrease in simulation F1 compared to simulation $\mathrm{S} 1$ is present, which is also in accordance with the $\mathrm{NO}_{\mathrm{x}}$ and $\mathrm{OH}$ changes between the two simulations.

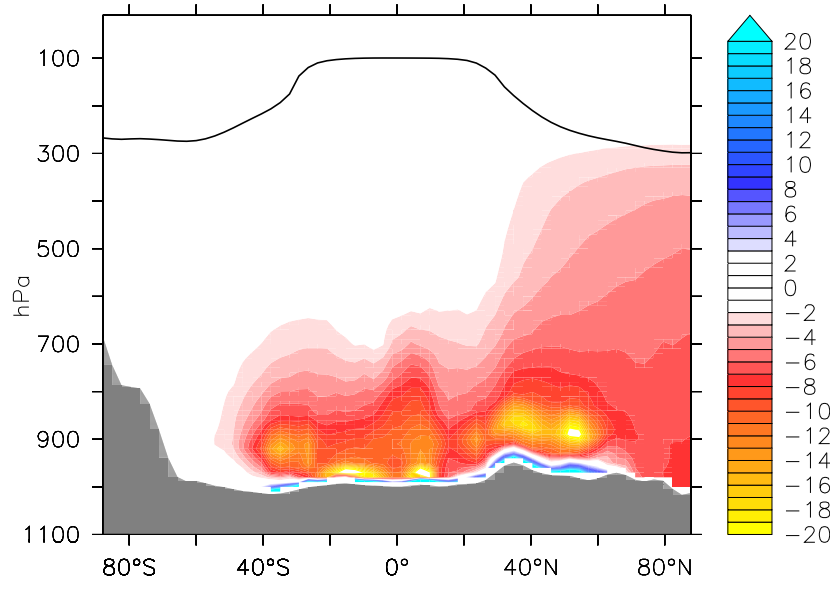

Fig. 3. Annually and zonally averaged relative differences (in \%) of $\mathrm{NO}_{\mathrm{y}}$ mixing ratios between simulation $\mathrm{F} 1$ and simulation $\mathrm{S} 1$ ((F1$\mathrm{S} 1) / \mathrm{S} 1)$.

The two model simulations show different characteristics for different regions (see Fig. 3). Compared to simulation S1,

- at the surface, simulation $\mathrm{F} 1$ shows an increase of $\mathrm{NO}_{\mathrm{x}}$ (more than 100\%) in polluted regions and a decrease of $\mathrm{NO}_{\mathrm{y}}$ in remote regions $(3-10 \%)$,

- in the PBL, simulation F1 shows a decrease of $\mathrm{NO}_{\mathrm{x}}$ due to the absence of emissions in the PBL above the surface in both, polluted and remote regions,

- in the free troposphere, simulation F1 shows a decrease of $\mathrm{NO}_{\mathrm{x}}$ and $\mathrm{NO}_{\mathrm{y}}(1-5 \%)$.

An overall reduction of the reactive nitrogen species at locations away from the sources is apparent in simulation F1 compared to simulation S1.

\section{$3.3 \mathrm{OH}_{\mathrm{x}}$}

The $\mathrm{HO}_{\mathrm{x}}$ family $\left(\mathrm{OH}+\mathrm{HO}_{2}\right)$ and the $\mathrm{NO}_{\mathrm{x}}$ family are strongly coupled, mainly through the reaction $\mathrm{NO}+\mathrm{HO}_{2} \rightarrow \mathrm{NO}_{2}+\mathrm{OH}$, leading to the recycling of $\mathrm{OH}$ and (with the photolysis of $\mathrm{NO}_{2}$ ) to the formation of ozone. Since simulation $\mathrm{F} 1$ predicts higher $\mathrm{NO}_{\mathrm{x}}$ mixing ratios at the surface in polluted regions, the $\mathrm{OH}$ mixing ratios are up to $20-30 \%$ higher than in simulation S1. Consistently, the $\mathrm{HO}_{2}$ mixing ratios are lower by about $30-40 \%$.

Due to the lower mixing ratios of $\mathrm{NO}_{\mathrm{x}}$ in simulation $\mathrm{F} 1$ in the remote regions (surface, PBL and free troposphere), the recycling of $\mathrm{OH}$ is less efficient. In addition, also the increased CO mixing ratios (although small) in simulation F1 with respect to simulation S1 contribute to decrease the $\mathrm{OH}$ mixing ratios in such regions. These processes induce a decreased mixing ratio of $\mathrm{OH}$ by 2 to $6 \%$ in simulation $\mathrm{F} 1$ compared to simulation S1. 


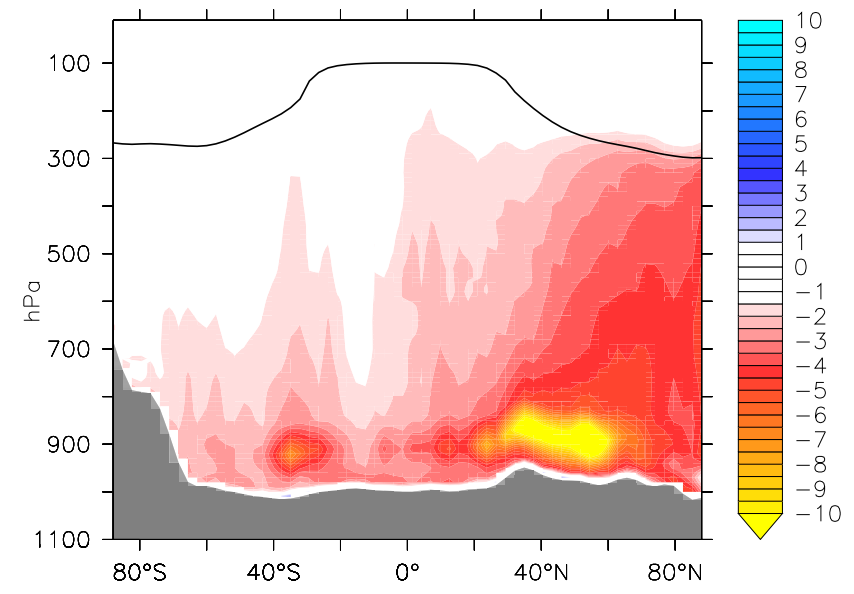

Fig. 4. Annually and zonally averaged relative differences (in \%) of $\mathrm{OH}$ mixing ratios between simulation $\mathrm{F} 1$ and simulation $\mathrm{S} 1$ ((F1$\mathrm{S} 1) / \mathrm{S} 1)$.

As shown in Fig. 4, the zonal average decrease is overall about $5 \%$ and about $10 \%$ in the PBL over the northern subtropics, where the emissions are large. In conclusion, although with height-independent emissions $\mathrm{OH}$ increases locally in polluted regions at the surface, the oxidation capacity of the atmosphere is globally reduced.

\subsection{Ozone $\mathrm{O}_{3}$}

Ozone chemistry in the troposphere is highly dependent on precursor species like $\mathrm{NO}_{\mathrm{x}}\left(=\mathrm{NO}+\mathrm{NO}_{2}\right), \mathrm{CO}$ and $\mathrm{NMHCs}$ (Atkinson, 2000; Logan, 1985; Houweling et al., 1998; Seinfeld and Pandis, 1997). Although simulation S1 and simulation F1 show very low differences in the free troposphere and in remote regions, large differences arise over polluted regions at the surface and in the PBL.

At the surface over polluted regions, the ozone mixing ratios are lower in simulation $\mathrm{F} 1$ than in simulation $\mathrm{S} 1$, despite the increase in $\mathrm{NO}_{\mathrm{x}}$ concentrations. This is mainly due to the increase of $\mathrm{NO}_{2}$ deposition in simulation $\mathrm{F} 1$ compared to simulation $\mathrm{S} 1$, which does not convert to $\mathrm{O}_{3}$ in simulation F1, while in simulation S1 the injection at higher altitude gives enough time for the interconversion. Although this gives generally smaller differences (in the range of 5$10 \%$ ), in some very polluted areas (mainly China), this gives a difference of up to $30 \%$. In remote regions the differences of $\mathrm{O}_{3}$ are smallest, where simulation $\mathrm{F} 1$ predicts lower mixing ratios than simulation simulation $\mathrm{S} 1(\simeq 2 \%)$, due to the lower abundance of $\mathrm{NO}_{\mathrm{x}}$.

In Table 3 the ozone production and loss terms are listed for simulation $\mathrm{S} 1$ and simulation F1. The results for the two simulations are comparable in terms of production and transport. This implies that the net exchange between troposphere and stratosphere (and likewise between the free troposphere and the PBL) is hardly influenced by the choice of the vertical distribution of emissions. The stratospheretroposphere exchange (STE) of ozone changes only by $3 \%$ between the two simulations $(10 \mathrm{Tg} /$ year). This is less than the inter-annual variability of the STE of ozone simulated by the model, which is about $25 \mathrm{Tg}$ /year (Jöckel et al., 2006). Also in the PBL the production and loss terms are similar in simulation F1 and simulation S1. This implies that the total amount of ozone produced is the same in both simulations, although the production is localised differently.

On the local scale, however, differences between the two simulations of up to $30 \%$ arise in polluted regions. In simulation $\mathrm{F} 1, \mathrm{O}_{3}$ production is reduced at the surface in polluted regions in comparison to simulation $\mathrm{S} 1$.

\section{Comparison with observations}

To provide an overview of the model performance for simulation S1 and simulation F1, a statistical comparison between observations and model results is presented. Observations are taken from ozone sondes observations (Logan, 1999; Thompson et al., 2003), from a collection of aircraft measurements (Emmons et al., 2000; Zbinden et al., 2006) and from a large number of multi-year surface measurements collected from the literature (Solberg et al., 1996; Lindskog and Moldanová, 1994; Bottenheim and Shepherd, 1995; Goldstein et al., 1995; Greenberg et al., 1996; Rudolph and Johnen, 1990; Rudolph et al., 1989; Clarkson et al., 1997).

An additional global dataset of surface measurements is the NOAA/ESSL flask sampling network (Novelli et al., 1998), which encompasses several years of CO measurements. For a quantitative statistical analysis, correlations between the model results and the aircraft observations are calculated with respect to the altitude, while the correlations between the model results and the surface measurements are calculated with respect to time.

\subsection{Comparison with ozone sondes}

The model results have been compared to climatologies obtained from ozone sonde observations. The first dataset used is the climatology compiled by Logan (1999). In Fig. 5, the measurement locations of these dataset are shown. While some ozone sonde observations have been performed in remote areas, others have been performed in industrialized areas (USA and Europe). However, the climatology presented by Logan (1999) has only a few levels close to the surface (1000 and $900 \mathrm{hPa}$ ). Since simulation S1 and simulation F1 are very similar in the free troposphere (i.e. with differences in tracer mixing ratios generally less than a few percent), we focus only on these two levels of the dataset. Correlations calculated between all available observations from this dataset at these pressure levels and model results from simulation $\mathrm{S} 1$ gives $\simeq 8 \%$ higher correlations than calculated with model results from simulation F1 $\left(R^{2}=0.47\right.$ vs. 0.43 , 
Table 3. Annual tropospheric ozone budget in $\mathrm{Tg}$ for the year 2000. RO2 comprises $\mathrm{C}_{2} \mathrm{H}_{5} \mathrm{O}_{2}, \mathrm{CH}_{3} \mathrm{C}(\mathrm{O}) \mathrm{OO}_{2} \mathrm{C}_{3} \mathrm{H}_{7} \mathrm{O}_{2}$, $\mathrm{CH}_{3} \mathrm{CH}\left(\mathrm{O}_{2}\right) \mathrm{CH}_{2} \mathrm{OH}, \mathrm{CH}_{3} \mathrm{COCH}_{2} \mathrm{O}_{2}, \mathrm{C}_{4} \mathrm{H}_{9} \mathrm{O}_{2}$, and peroxy radicals resulting from oxidation of MVK, MEK and isoprene.

\begin{tabular}{|c|c|c|c|c|c|c|c|c|c|c|c|c|}
\hline & \multicolumn{6}{|c|}{ troposphere } & \multicolumn{6}{|c|}{ planetary boundary layer } \\
\hline & \multicolumn{3}{|c|}{ simulation $\mathrm{S} 1$} & \multicolumn{3}{|c|}{ simulation F1 } & \multicolumn{3}{|c|}{ simulation S1 } & \multicolumn{3}{|c|}{ simulation F1 } \\
\hline & $\mathrm{NH}$ & SH & Global & $\mathrm{NH}$ & $\mathrm{SH}$ & Global & $\mathrm{NH}$ & SH & Global & $\mathrm{NH}$ & $\mathrm{SH}$ & Global \\
\hline $\mathrm{NO}+\mathrm{HO}_{2}$ & 1887 & 1248 & 3135 & 1854 & 1242 & 3096 & 724 & 323 & 1047 & 704 & 316 & 1020 \\
\hline $\mathrm{NO}+\mathrm{RO}_{2}$ & 382 & 194 & 576 & 377 & 192 & 569 & 253 & 121 & 374 & 250 & 119 & 369 \\
\hline $\mathrm{NO}+\mathrm{CH}_{3} \mathrm{O}_{2}$ & 683 & 456 & 1139 & 659 & 446 & 1105 & 275 & 141 & 416 & 265 & 137 & 402 \\
\hline Total Production & 2952 & 1898 & 4850 & 2890 & 1880 & 4770 & 1252 & 585 & 1837 & 1219 & 572 & 1791 \\
\hline $\mathrm{O}_{3}+\mathrm{OH}$ & -310 & -219 & -529 & -297 & -213 & -510 & -74 & -40 & -114 & -69 & -38 & -107 \\
\hline $\mathrm{O}_{3}+\mathrm{HO}_{2}$ & -824 & -557 & -1380 & -814 & -557 & -1371 & -208 & -110 & -318 & -203 & -108 & -311 \\
\hline $\mathrm{H}_{2} \mathrm{O}+\mathrm{O}^{1}(\mathrm{D})$ & -1422 & -1089 & -2511 & -1404 & -1085 & -2489 & -498 & -358 & -856 & -489 & -355 & -844 \\
\hline Total Losses & -2556 & -1865 & -4421 & -2515 & -1855 & -4370 & -780 & -508 & -1288 & -761 & -501 & -1262 \\
\hline net & 396 & 33 & 429 & 375 & 25 & 400 & 472 & 77 & 549 & 458 & 71 & 529 \\
\hline dry deposition & -507 & -273 & -780 & -488 & -268 & -756 & -507 & -273 & -780 & -488 & -268 & -756 \\
\hline change in burden & -3 & 1 & -2 & 2 & 1 & 3 & 1 & 0 & 1 & 1 & -1 & 0 \\
\hline burden & 172 & 150 & 322 & 174 & 151 & 325 & 16 & 9 & 25 & 16 & 8 & 24 \\
\hline Transport $^{\mathrm{a}}$ & 108 & 241 & 349 & 115 & 244 & 359 & 36 & 196 & 232 & 31 & 196 & 227 \\
\hline
\end{tabular}

a net downward; derived from budget closure; accounts also for upward transport.

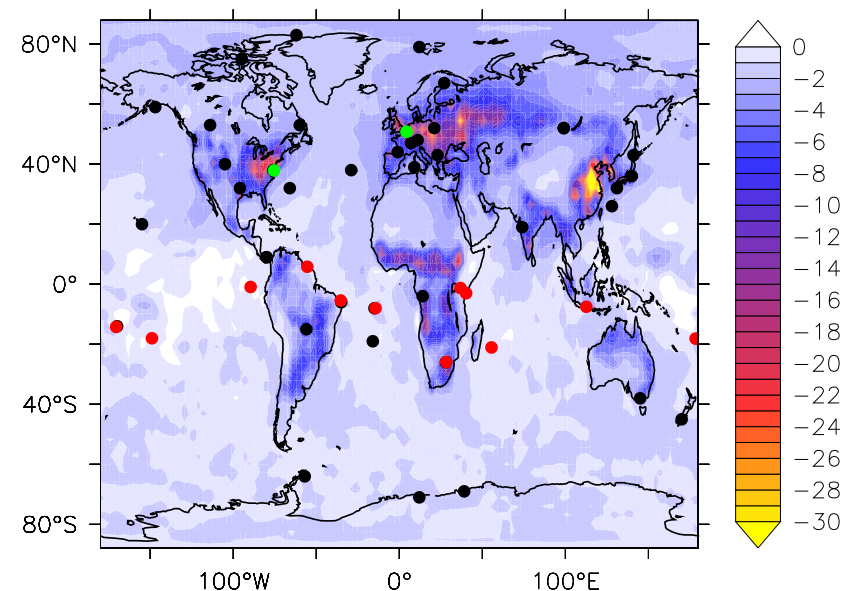

Fig. 5. Annually and zonally averaged relative differences (in \%) of $\mathrm{O}_{3}$ mixing ratios between simulation $\mathrm{F} 1$ and simulation $\mathrm{S} 1$ ((F1$\mathrm{S} 1) / \mathrm{S} 1)$. Black circles denote measurement sites from the LOGAN (Logan, 1999) dataset, red circles from the SHADOZ (Thompson et al., 2003) dataset. The green circles denote Uccle stations (Belgium) and Wallop island station (USA).

respectively). However, the low correlations refrain us to draw any conclusion here.

Because of their sparse geographical distribution (see Fig. 5), some of the stations are at locations with high differences between simulation $\mathrm{S} 1$ and simulation F1, while others are at locations with virtually no differences between the two simulations. In Fig. 6, the Taylor diagrams (Taylor, 2001) of the comparison between the model simulations and the ozone sonde observations is presented. There is no clear difference

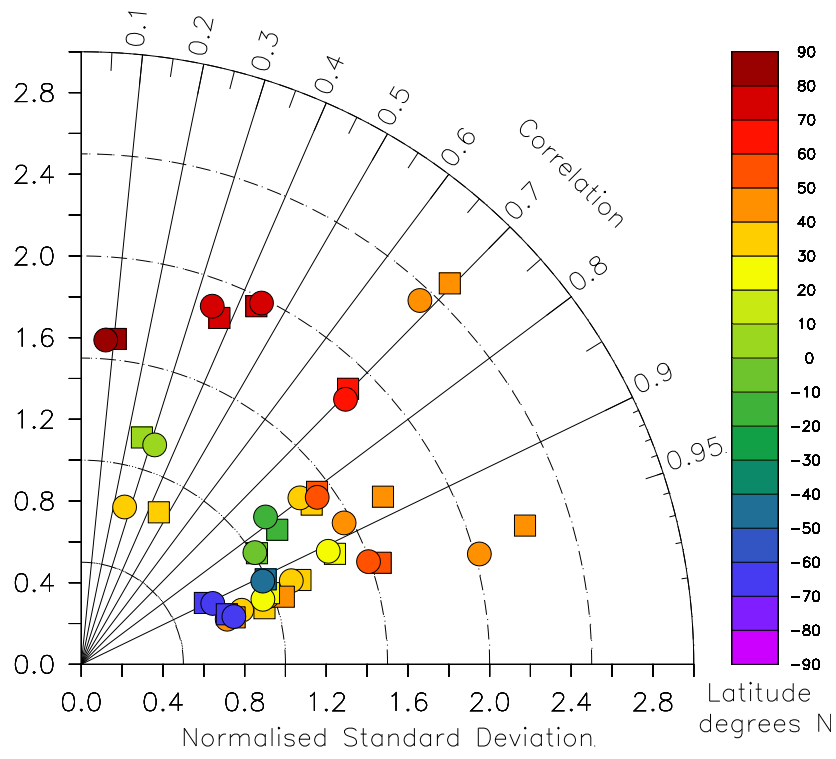

Fig. 6. Normalised Taylor diagram of the comparison between ozone sonde observations from the Logan (1999) dataset and model results at $900 \mathrm{hPa}$. Comparison with the model results from simulation $\mathrm{S} 1$ and simulation $\mathrm{F} 1$ are denoted with squares and circles, respectively. The colors denote the latitude of the stations.

between the two simulations when compared to the observations at $900 \mathrm{hPa}$. At some locations the model results from simulation S1 agree better with the observations and in others the model results from simulation F1 agree better with the observations. The largest differences (as expected) are at locations between $30^{\circ}$ and $60^{\circ} \mathrm{N}$. Nevertheless, the results 

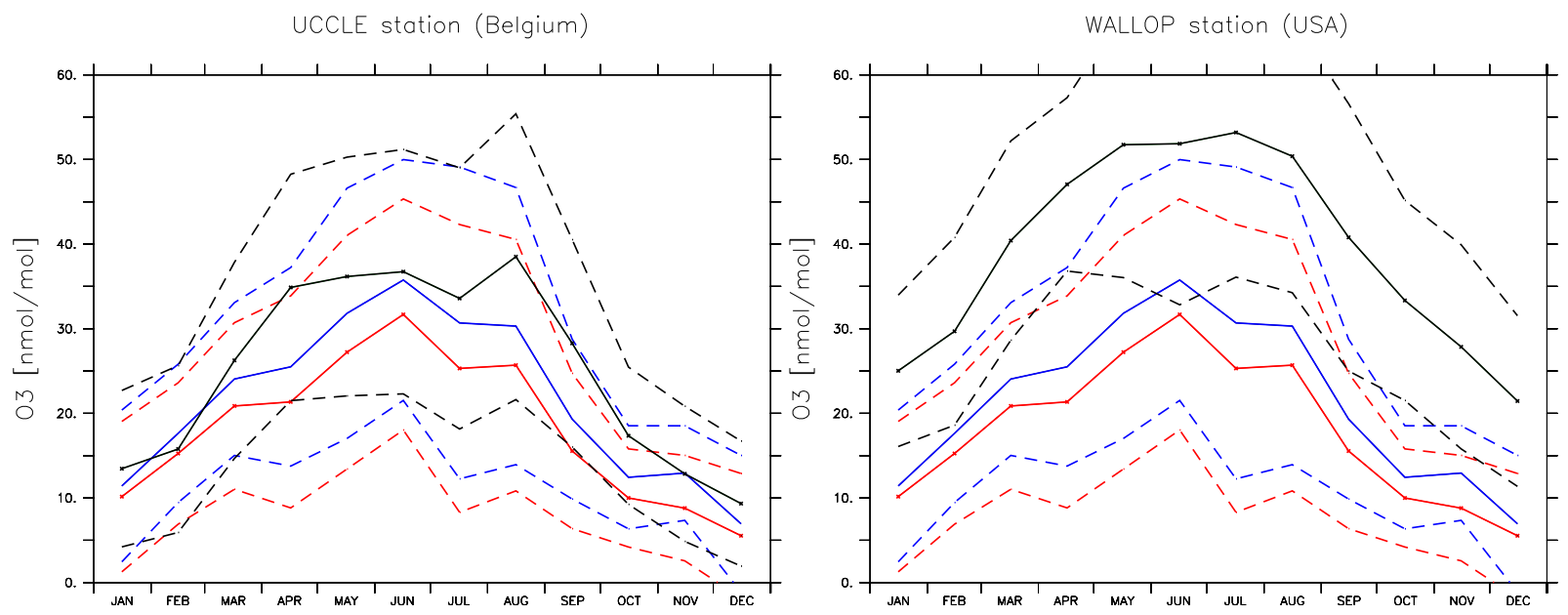

Fig. 7. Comparison of simulated and observed $\mathrm{O}_{3}$ mixing ratios in $\mathrm{nmol} / \mathrm{mol}$. The monthly climatology from observations are indicated in black, while the model results are represented in blue and red lines for simulation S1 and simulation F1, respectively. The corresponding simulated standard deviations with respect to time are represented by the dashed lines.

are not clearly indicating which simulation is better in reproducing the observations.

A further dataset based on ozone sondes used in this comparison is the one based on the SHADOZ project (Thompson et al., 2003), which covers tropical regions (see Fig. 5). The observations, in fact, are mainly located in the Pacific Ocean where the differences between simulation S1 and F1 are only a few percent. Also the few observations over the Atlantic ocean are either located in coastal or in open ocean regions. Since there the differences between simulation S1 and F1 at these locations are in the order of $\sim 0-5 \%$ only, they are not regarded as being significant. In this dataset only one location (namely Irene, South Africa) shows a somewhat strong difference at the surface between the two simulations. Based on this single station, we obtain a $\sim 10 \%$ better correlation between simulation S1 and the observations $\left(R^{2}=0.22\right)$ than between simulation $\mathrm{F} 1$ and the observations $\left(R^{2}=0.20\right)$, based on data below $900 \mathrm{hPa}$ (lowest measurement levels). However, as for the previous dataset, the low correlation does not allow us to draw any conclusion. Nevertheless, the average difference at the lowest level of the measurements between simulation S1 and Irene ozone sonde $(-1.19 \mathrm{nmol} / \mathrm{mol})$ is smaller than the one calculated with the same observational data but model results from simulation F1 $(-1.71 \mathrm{nmol} / \mathrm{mol})$.

In order to achieve a clear picture of the different performances of the two simulations a further analysis was performed for two specific sites, whose location was carefully selected: Uccle station (Belgium) and Wallops island station (USA) (WOUDC, 2009). Both stations are at locations with large differences between simulation S1 and simulation F1 and, in addition, extensive data for the period 1995-2005 are available. From the observations taken at these two locations during the 1995-2005 period, a monthly climatology has been calculated. Focusing the analysis on the surface $(\sim 1000 \mathrm{hPa})$, we compare the seasonal cycle of model results and the calculated climatology (see Fig. 7). Although the correlation between the model simulations and the climatology shows no significant differences (only $\sim 3 \%$ ), the results from simulation S1 agree better with the observations compared to results from simulation F1. In fact (see Fig. 7), the average bias at Uccle station between simulation $\mathrm{S} 1$ and the observations is $\sim 50 \%$ lower $(-3.6 \mathrm{nmol} / \mathrm{mol})$ than the average bias between simulation F1 and the observations $(-7.14 \mathrm{nmol} / \mathrm{mol})$. Coherently, the average bias at Wallop station between simulation S1 and the observations is $\sim 20 \%$ lower $(-17.8 \mathrm{nmol} / \mathrm{mol})$ than the average bias between simulation $\mathrm{F} 1$ and the observations $(-21.2 \mathrm{nmol} / \mathrm{mol})$.

\subsection{Comparison with aircraft measurements}

The field campaigns used in this study are "data composites" of different species and are a basis to create observationbased climatologies (Emmons et al., 2000). The measurements have been averaged over the entire field campaign region and organized as vertically gridded data. Hence, in case of the comparison with aircraft campaigns, the model results have been averaged over the same region and time of the year of the field campaign, interpolating only the vertical axis to the observational grid ( $1 \mathrm{~km}$ resolution).

Although the specific field campaign data is, strictly speaking, only representative for the specific year, the averaging of the measurements over space and time partly solves the problem of interannual variability, so that these data can be considered as climatology. To confirm that our results are independent on the analysed year, we calculated the correlation between the model results (for $\mathrm{CO}$ and $\mathrm{O}_{3}$ of simulation S1) of different years (2000-2004) with the data-composites 
Table 4. Summary of the correlation coefficients $\left(R^{2}\right)$ and linear regression analysis of model results versus aircraft observations (model $=m \times$ measurement $+b$ ). Bias and $b$ are in $\mathrm{pmol} / \mathrm{mol}$; bias=model results minus observations.

\begin{tabular}{|c|c|c|c|c|c|c|c|c|c|c|c|}
\hline \multirow[b]{2}{*}{ trace gas } & \multirow[b]{2}{*}{ num. obs. } & \multicolumn{4}{|c|}{ simulation $\mathrm{S} 1$} & \multicolumn{4}{|c|}{ simulation F1 } & \multirow{2}{*}{$\begin{array}{c}\text { bias ratio } \\
(\mathrm{F} 1 / \mathrm{S} 1)\end{array}$} & \multirow{2}{*}{$\begin{array}{l}R^{2} \text { ratio } \\
(\mathrm{F} 1 / \mathrm{S} 1)\end{array}$} \\
\hline & & bias & $m$ & $b$ & $R^{2}$ & bias & $m$ & $b$ & $R^{2}$ & & \\
\hline $\mathrm{C}_{2} \mathrm{H}_{4}$ & 454 & -23.87 & 0.26 & 9.97 & 0.41 & -20.39 & 0.47 & 4.45 & 0.51 & 0.85 & 1.24 \\
\hline $\mathrm{C}_{2} \mathrm{H}_{6}$ & 473 & -174.03 & 0.69 & 78.69 & 0.80 & -156.7 & 0.71 & 82.12 & 0.80 & 0.90 & 1.00 \\
\hline $\mathrm{C}_{3} \mathrm{H}_{6}$ & 332 & -11.50 & 0.14 & 0.27 & 0.41 & -10.36 & 0.37 & -1.84 & 0.63 & 0.90 & 1.54 \\
\hline $\mathrm{C}_{3} \mathrm{H}_{8}$ & 472 & -18.82 & 0.92 & -5.75 & 0.77 & -13.32 & 0.94 & -4.54 & 0.76 & 0.70 & 0.99 \\
\hline $\mathrm{CH}_{3} \mathrm{COCH}_{3}$ & 246 & -376.85 & 0.42 & -28.72 & 0.38 & -376.07 & 0.43 & -32.68 & 0.38 & 1.00 & 1.00 \\
\hline $\mathrm{CH}_{3} \mathrm{OH}$ & 116 & -447.82 & 0.18 & 255.18 & 0.31 & -452.41 & 0.20 & 248.00 & 0.30 & 1.01 & 0.96 \\
\hline $\mathrm{HCHO}$ & 213 & 6.41 & 0.74 & 55.79 & 0.63 & 7.66 & 0.80 & 45.16 & 0.60 & 1.19 & 0.95 \\
\hline $\mathrm{H}_{2} \mathrm{O}_{2}$ & 411 & 3.73 & 0.63 & 275.81 & 0.55 & 26.83 & 0.65 & 289.34 & 0.55 & 7.19 & 1.00 \\
\hline $\mathrm{HNO}_{3}$ & 416 & -13.05 & 0.53 & 63.11 & 0.34 & -16.61 & 0.53 & 58.34 & 0.34 & 1.27 & 1.00 \\
\hline $\mathrm{O}_{3}$ & 506 & 11835 & 1.78 & -28464 & 0.54 & 11740 & 1.8 & -29496 & 0.53 & 0.99 & 0.98 \\
\hline $\mathrm{CO}$ & 456 & -8621.8 & 0.51 & 36381 & 0.63 & -7170.6 & 0.53 & 35868 & 0.59 & 0.83 & 0.93 \\
\hline $\mathrm{NO}$ & 417 & 2.3 & 0.59 & 7.75 & 0.29 & -0.61 & 0.80 & 4.47 & 0.30 & 1.94 & 1.03 \\
\hline
\end{tabular}

from the field campaigns. The difference in the correlation is in the range of a few percent $( \pm 5 \%$ and $\pm 4 \%$ for $\mathrm{CO}$ and $\mathrm{O}_{3}$, respectively), while the difference in the bias is somewhat higher, but still in the range of a few percent $( \pm 7 \%$ and $\pm 5 \%$ for $\mathrm{CO}$ and $\mathrm{O}_{3}$, respectively). To resume, the interannual variability cannot be neglected per se. However, thanks to the usage of data composites obtained from long aircraft field campaigns, the results obtained are almost independent on the selected year. Hence, only the year 2000 from simulation $\mathrm{S} 1$ and simulation $\mathrm{F} 1$ has been used in the comparison. Table 4 summarises the comparison of model results from simulation S1 and simulation F1 with measurements on board of aircraft. The majority of the measurements included in this study have been collected in remote regions or downwind of polluted regions, where, as shown in Sects. 3.2-3.4, the differences between simulation $\mathrm{S} 1$ and simulation F1 are small or in the range of the measurement variabilities. In fact, no significant differences between the two simulations are found when they are compared with these aircraft observations. In the measurement regions, the vertical distributions of these tracers show the same patterns and the same magnitude. The correlation between simulation $\mathrm{S} 1$ and the observations is overall larger (see $\mathrm{C}_{2} \mathrm{H}_{4}$ and $\mathrm{C}_{3} \mathrm{H}_{6}$ ) or equal to $\left(\mathrm{C}_{2} \mathrm{H}_{6}, \mathrm{C}_{4} \mathrm{H}_{8}, \mathrm{CH}_{3} \mathrm{COCH}_{3}, \mathrm{H}_{2} \mathrm{O}_{2}, \mathrm{HNO}_{3}, \mathrm{O}_{3}\right.$ and $\mathrm{NO}$ ) than the respective correlation calculated between the results of simulation F1 and the observations.

Since the aircraft campaigns took mainly place in remote regions, significant differences between simulation $\mathrm{S} 1$ and simulation F1 occur only at a few locations (see Fig. 2). Only a few aircraft campaigns in the dataset include polluted/partially polluted regions.

An example is presented in Fig. 8, where vertical profiles at a polluted location (left, TOPSE-May, Churchill) and at a location downwind of a polluted region (right, TRACE-P,
China) are shown. The mixing ratios at the surface calculated from simulation F1 are larger than those from simulation S1 (a factor of 3 in TRACE-P, China). In contrast, between $600 \mathrm{~m}$ and $\sim 1.5 \mathrm{~km}$ altitude, the opposite is visible, the mixing ratios from simulation $\mathrm{S} 1$ being larger than those from simulation F1 (see Sect. 3.2). Moreover, at the surface (see Fig. 8, TRACE-P, China), simulation S1 is closer to the observed value, which is the average of 389 measurements taken during the campaign period in the region at that level. In the free troposphere, however, no substantial differences are noticeable between the two simulations.

In Fig. 9, results for $\mathrm{CO}$ from both simulations are compared with measurements from the TRACE-A field campaign (Talbot et al., 1996). Although this field campaign was strongly influenced by biomass burning emissions, the differences between the two simulation in these locations are similar to what has been seen for NO in case of locations with strong anthropogenic influence. In both cases, despite the emissions altitude, the free troposphere is almost not influenced, while at the surface we find significant differences. This confirms the low (less than 2\%) sensitivity of the trace gas distributions to the vertical distribution of emissions in remote regions and the free troposphere shown in Sect. 3. In particular, the measurements at the surface (see TRACE-A, E-Brazil) show that simulation $\mathrm{S} 1$ better represents $\mathrm{CO}$ in this region than simulation F1. The Trace-A campaign took place during the Southern Hemisphere dry season and some flights were influenced by biomass burning (Talbot et al., 1996). It can be concluded that the vertical distribution of the emissions (simulation S1) yields more realistic results than the setup with emissions confined to the surface layer (simulation F1). This confirms previous findings (see Turquety et al., 2007, and references therein) that biomass burning emissions should be vertically distributed, although no 

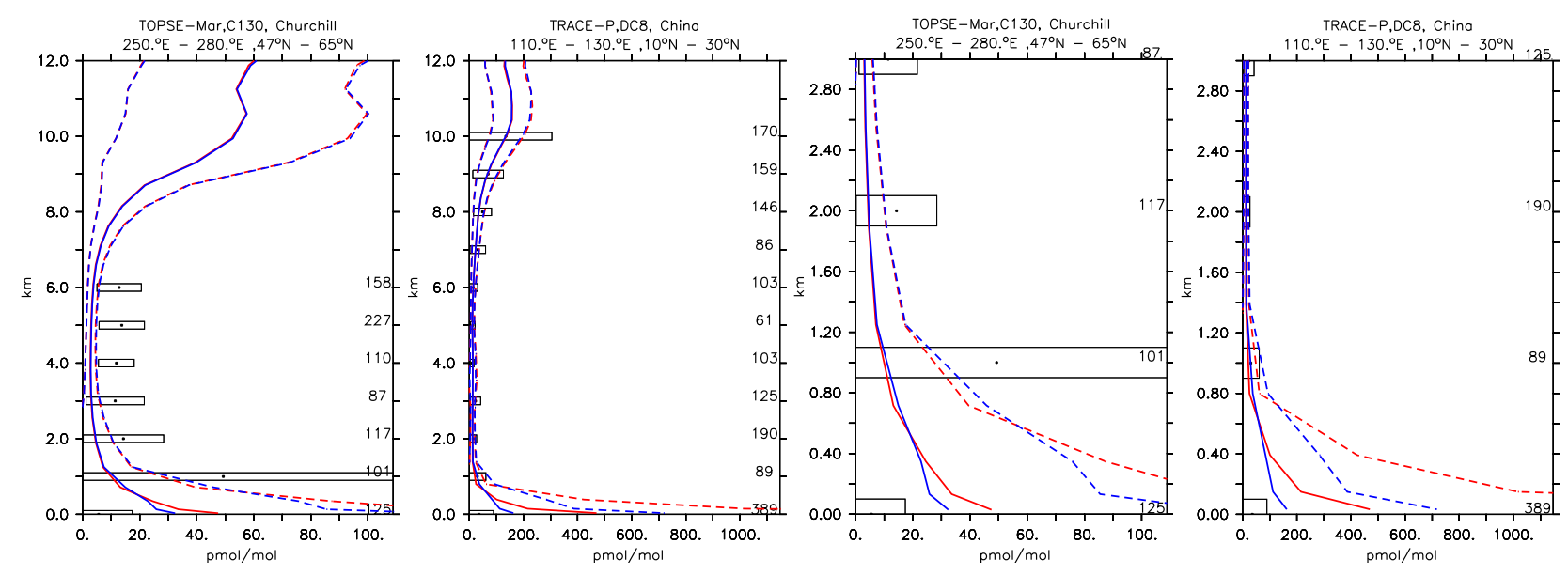

Fig. 8. Vertical profiles of NO (in pmol/mol) for some selected campaigns from Emmons et al. (2000). Asterisks and boxes represent the average and the standard deviation (w.r.t. space and time) of the measurements in the region, respectively. The simulated averages are indicated by the red and blue lines, for simulation F1 and simulation S1 respectively. The corresponding simulated standard deviations w.r.t. time and space are represented by the dashed lines. On the right axis the numbers of measurements are listed. The left and the right graphs represent represent the same data with different vertical axes.
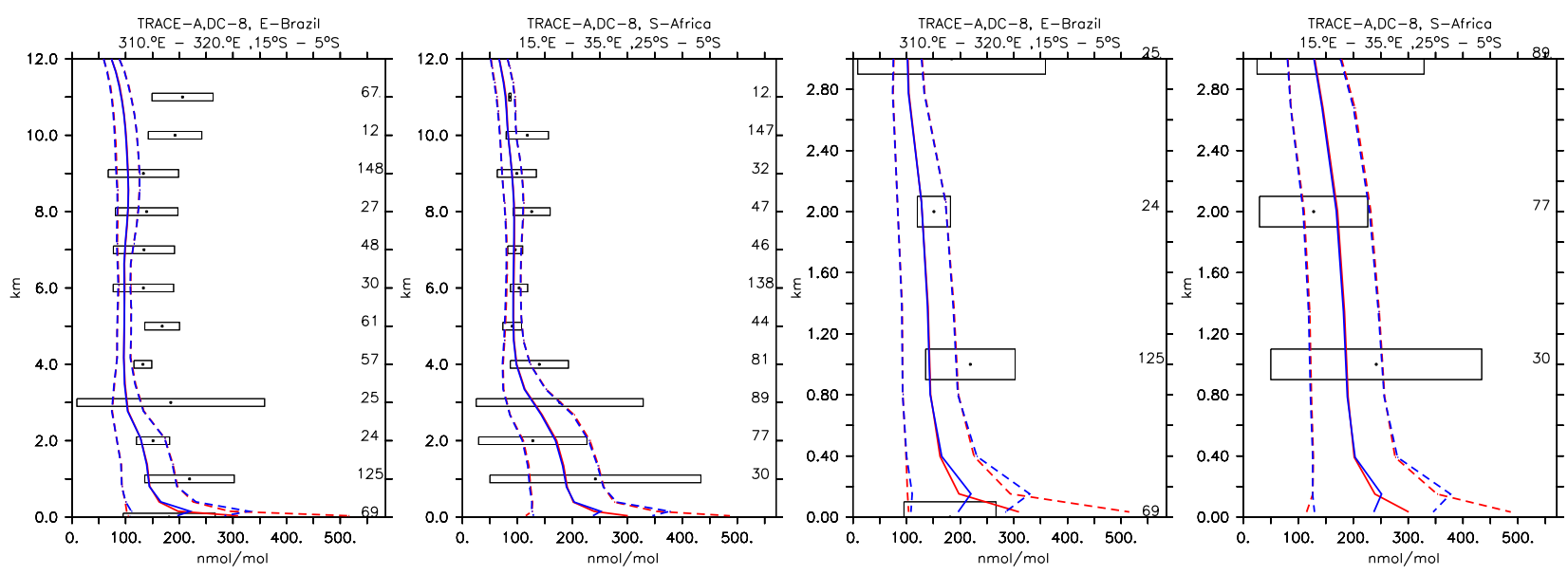

Fig. 9. As Fig. 8 for $\mathrm{CO}$ in $\mathrm{nmol} / \mathrm{mol}$, for different regions.

real indication of an ideal vertical emission distribution can be derived from this comparison.

A further analysis can be performed with the data from the MOZAIC project (Measurement of OZone by Airbus Inservice Aircraft). The only published climatology from this dataset is the one from Zbinden et al. (2006). This seasonal climatology consists of ozone vertical profiles at a few places (e.g., Japan region, New York, Paris and Frankfurt). The observational data (and the simulated data) have been restricted to altitudes between the surface and $4000 \mathrm{~m}$, to include only the tropospheric region where most of the differences between simulation $\mathrm{S} 1$ and simulation $\mathrm{F} 1$ are expected. A correlation calculation with respect to time does not give robust results, because the database represents a seasonal climatology. Instead a correlation with respect to the vertical axis has been performed and the results are presented in Fig. 10. In addition, the average bias between simulations and observations for all seasons and for each location is listed in Fig. 10.

These results do not conclusively define which simulation is the best in reproducing the observational data. In fact, results from simulation F1 have lower differences to the observations than simulation S1 in Paris and Frankfurt, while simulation S1 shows lower differences to the observations than simulation F1 in Japan region and New York. In addition, the vertical profiles from both model simulations correlate similarly with the observations. Hence, also this database does not clearly show which simulation is performing better: as example, for the New York region, results from simulation S1 correlate better than results from simulation F1 with the summer observations, while, for the winter observations, 


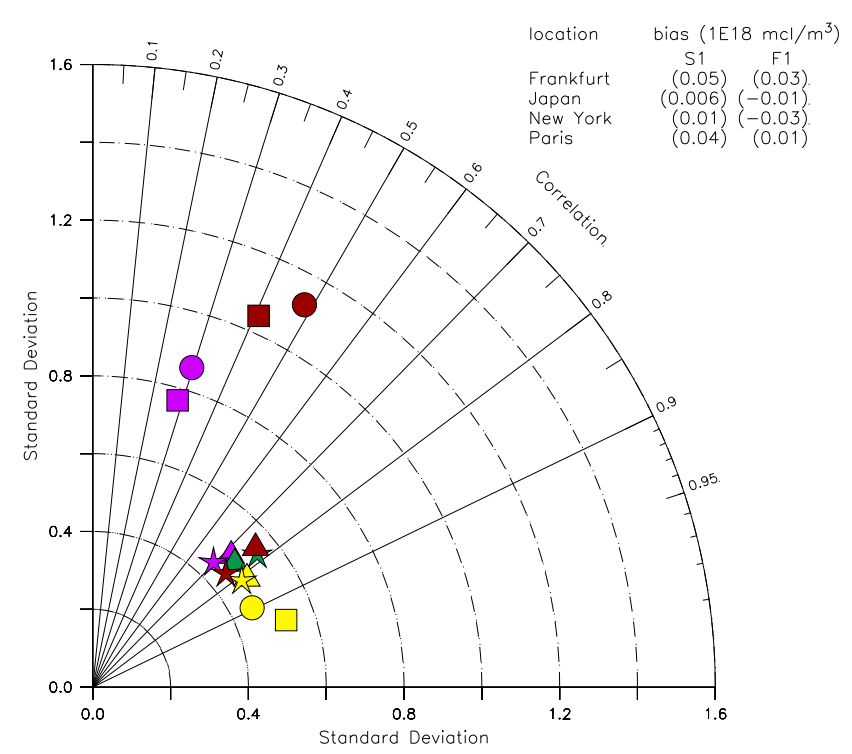

Fig. 10. Normalised Taylor diagram of the comparison between MOZAIC observations and model results between the surface and $4000 \mathrm{~m}$. Comparison for summer observations with the model results from simulation $\mathrm{S} 1$ and simulation $\mathrm{F} 1$ are denoted with squares and circles, respectively. Comparison for winter observations with the model results from simulation $\mathrm{S} 1$ and simulation $\mathrm{F} 1$ are denoted with stars and triangles, respectively. The colors denote the location, i.e., Frankfurt in pink, Japan region in green, New York in yellow and Paris in red.

results from simulation $\mathrm{F} 1$ correlate better than results from simulation $\mathrm{S} 1$.

\subsection{Comparison with station observations}

A striking different picture arises when simulation $\mathrm{S} 1$ and simulation F1 are compared to surface observations. As mentioned in the previous sections (from Sect. 3.1 to Sect. 3.2) simulation $\mathrm{F} 1$ shows higher mixing ratios at the surface in polluted regions than simulation $\mathrm{S} 1$, in particular for $\mathrm{CO}$, $\mathrm{NO}_{\mathrm{y}}$ and $\mathrm{HO}_{\mathrm{x}}$. In contrast to the aircraft measurements, the set of observational sites comprise also stations located in industrialised regions (e.g., Egbert, Canada) or downwind source regions (e.g., Rucava, Latvia), giving the opportunity to evaluate the model at locations where the effect of changing the vertical emissions distributions is large.

As shown in Table 5, results from simulation S1 agree by far better with the observations than the results from simulation F1. The correlations between the tracer mixing ratios of simulation S1 and the observations are 20-30\% larger than the respective correlations of simulation F1. Moreover, the bias between simulation S1 and the observations is generally lower (about 30\%) than the respective bias of simulation $\mathrm{F} 1$, with the exception of acetaldehyde $\left(\mathrm{CH}_{3} \mathrm{CHO}\right)$ and formaldehyde (HCHO). In the case of acetaldehyde, the model poorly represents this tracer (see Pozzer et al. (2007),

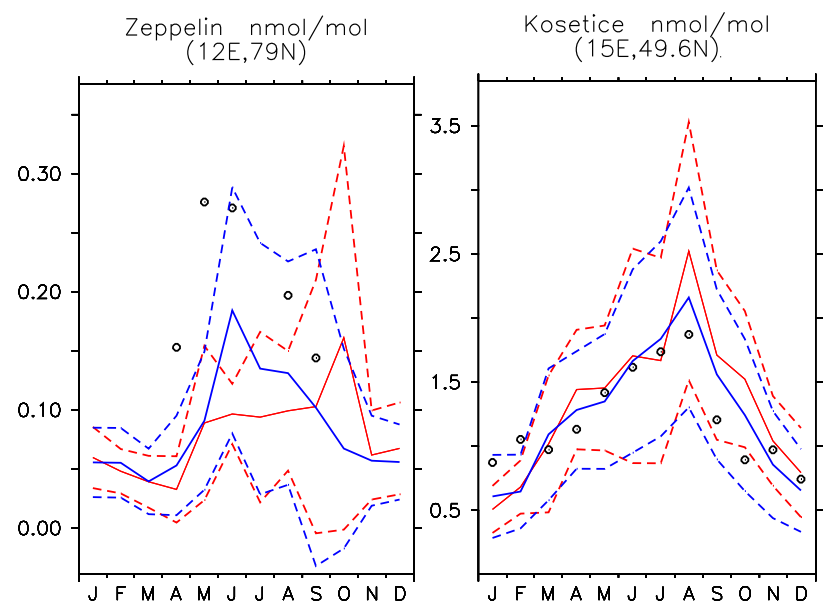

Fig. 11. Seasonal cycle (monthly averages) of $\mathrm{HCHO}$ (in $\mathrm{nmol} / \mathrm{mol}$ ) for some selected locations at the surface (Solberg et al., 1996). Model: solid line; model standard deviation: dashed line; measurements: circles. The red and blue lines indicate results from simulation F1 and simulation S1, respectively.

confirmed by the very low correlation between model and observations). Hence no real conclusion can be drawn for this specific tracer. In the case of formaldehyde (HCHO), however, the model is generally representing the observations quite accurately, although with a certain overestimation. The differences between simulation $\mathrm{S} 1$ and simulation $\mathrm{F} 1$ in bias and correlation for $\mathrm{HCHO}$ are due to the different behaviour of the two simulations at Zeppelin (see Fig. 11). At this location, where the correlations of the two simulations with the observations largely differ (the phase of the seasonal cycle of mixing ratios from simulation F1 and simulation $\mathrm{S} 1$ are different), the low values from simulation F1 balance the general overestimation obtained at other stations, when the bias is calculated. Hence, it can be concluded that the decrease of the bias between observations and simulation $\mathrm{F} 1$ compared to simulation $\mathrm{S} 1$ is an artefact. In addition, Fig. 11 (Zeppelin station) shows a better agreement of the measurements with the results from simulation S1 than with those from simulation $\mathrm{F} 1$.

Peculiar is acetone $\left(\mathrm{CH}_{3} \mathrm{COCH}_{3}\right)$, which is mainly emitted biogenically, with only a few percent contribution of anthropogenic origin (Jacob et al., 2002, and references therein). Hence, the acetone mixing ratio shows differences between simulation S1 and simulation F1 mainly due to indirect effects, such as local changes in the oxidation capacity and/or different degradation of acetone precursors.

Here, we only show ethane $\left(\mathrm{C}_{2} \mathrm{H}_{6}\right)$, one of the best simulated tracers in the model (Pozzer et al., 2007). In Fig. 12 observations and model results are compared.

The average values are comparable between the two simulations. Differences arise especially during summer, e.g., in Rorvik, Birkenes, or Egbert, where simulation F1 shows larger mixing ratios as simulation S1. Here, results from 
Table 5. Summary of the correlation coefficients and linear regression analysis of model results versus station observations $($ model $=m(\times)$ measurement $+b)$. Bias and $b$ are in $\mathrm{nmol} / \mathrm{mol}$; bias $=$ model results minus observations.

\begin{tabular}{lccccccccccc}
\hline & & \multicolumn{4}{c}{ simulation $\mathrm{S} 1$} & \multicolumn{4}{c}{ simulation $\mathrm{F} 1$} & \multicolumn{3}{c}{$\begin{array}{c}\text { bias ratio } \\
\text { trace gas }\end{array}$} & num. obs. & bias & $m$ & $b$ & $R^{2}$ & bias & $m$ & $b$ & $R^{2}$ & $(\mathrm{~F} 1 / \mathrm{S} 1)$ & $(\mathrm{F} 1 / \mathrm{S} 1)$ \\
\hline $\mathrm{C}_{2} \mathrm{H}_{4}$ & 138 & 0.20 & 0.53 & 0.50 & 0.40 & 0.28 & 0.50 & 0.60 & 0.30 & 1.40 & 0.75 \\
$\mathrm{C}_{2} \mathrm{H}_{6}$ & 150 & 0.24 & 0.83 & 0.54 & 0.54 & 0.32 & 0.77 & 0.72 & 0.42 & 1.33 & 0.77 \\
$\mathrm{C}_{3} \mathrm{H}_{6}$ & 137 & 0.01 & 0.66 & 0.06 & 0.50 & 0.03 & 0.64 & 0.82 & 0.41 & 3.00 & 0.82 \\
$\mathrm{C}_{3} \mathrm{H}_{8}$ & 150 & 0.61 & 1.13 & 0.51 & 0.42 & 0.66 & 1.06 & 0.62 & 0.35 & 1.08 & 0.83 \\
$\mathrm{CH}_{3} \mathrm{CHO}$ & 77 & 0.15 & 0.20 & 0.58 & 0.08 & 0.14 & 0.15 & 0.60 & 0.04 & 0.94 & 0.50 \\
$\mathrm{CH}_{3} \mathrm{COCH}$ & 81 & -0.08 & 0.53 & 0.46 & 0.51 & -0.09 & 0.54 & 0.43 & 0.47 & 1.13 & 0.92 \\
$\mathrm{HCHO}_{3}$ & 65 & -0.11 & 0.47 & 0.50 & 0.55 & -0.08 & 0.44 & 0.55 & 0.45 & 0.72 & 0.81 \\
$\mathrm{CO}^{\mathrm{a}}$ & 4224 & 5.67 & 0.98 & 6.50 & 0.67 & 9.16 & 1.00 & 13.72 & 0.60 & 1.61 & 0.89 \\
\hline
\end{tabular}

a from NOAA/ESSL flask sampling network (see Sect. 3.1).

simulation $\mathrm{F} 1$ are in clear contrast to the observations (see Fig. 12).

Also for $\mathrm{CO}$ the correlation between station measurements and simulated mixing ratios is higher for simulation $\mathrm{S} 1$ than for simulation F1, yet the difference is smaller than for other trace gases. In fact, the correlation between station observations and simulation $\mathrm{S} 1$ and the correlation between station observations and simulation F1 differ by only $\simeq 10 \%$, which is less than what is observed for other tracers (where a difference of $\simeq 20-25 \%$ is present).

As pointed out by Haas-Laursen and Hartley (1997), the flask samples were collected under non-polluted conditions, i.e. for stations close to local sources only certain wind directions have been selected to avoid local contamination. Hence, the effect of the different vertical distributions of emissions is lower for $\mathrm{CO}$ at these locations (see also Sect. 3.3).

As shown in Fig. 13, results from simulation $\mathrm{S} 1$ and simulation F1 hardly differ. It can hence be confirmed that for background conditions the different vertical emissions distributions do not change the simulated surface mixing ratios considerably (about 1\%, see Sect. 3.1).

\section{Conclusions}

The ECHAM5/MESSy atmospheric chemistry (EMAC) general circulation model was used to investigate the effect of height dependent emissions on tropospheric chemistry. Two simulations were performed and the results compared. In one simulation (simulation F1) the anthropogenic and biomass burning emissions were confined to the surface layer, while in the second (simulation S1) the anthropogenic emissions have been distributed vertically to 6 different altitudes, while biomass burning emissions have been injected at a constant altitude. The resulting trace gas distributions of the two simulations do not differ considerably in remote regions and in the free troposphere, with differences of less than 5\%. How- ever, large differences occur at the surface in polluted regions, with differences of more than $100 \%$, depending on the species.

A comparison of the model results with data from ozone sonde, various aircraft field campaigns and surface stations have been used to evaluate the simulations. The comparison with ozone sonde climatologies does not clearly indicate which simulation achives the better agreement with observations. However, climatology ad hoc compiled for two specific stations shows that model results from simulation $\mathrm{S} 1$ have a lower bias with the observations than model results from simulation F1.

The aircraft field campaigns mainly took place in unpolluted regions, therefore results from both simulations correlate similarly to those observations and no significant difference can be detected. In contrast to this, the correlation of the model results to the surface observations, which include also polluted locations, is significantly (10-30\%, depending on the species) reduced, if the emissions are confined to the surface. For alkanes and alkenes, a 20 to $30 \%$ percent decrease of the correlation coefficient is calculated, while for $\mathrm{CO}$ a decrease of $10 \%$ is derived. The lower sensitivity of $\mathrm{CO}$ can be traced back to the used database, since the observations in the database have been filtered for non-polluted conditions.

In addition to the improved correlation, also the bias between simulated and observed mixing ratios is reduced, if the emissions are vertically distributed. We conclude that results of an atmospheric chemistry general circulation model in remote regions are hardly affected by the chosen vertical distribution of the emissions, whereas the information about the vertical distribution of emissions is essential to reproduce correctly the chemistry in polluted regions.

To improve the process of emissions in such models, further research is required. A more realistic approach might be to connect the vertical distribution of emissions consistently to the simulated meteorological situation (e.g. vertical 

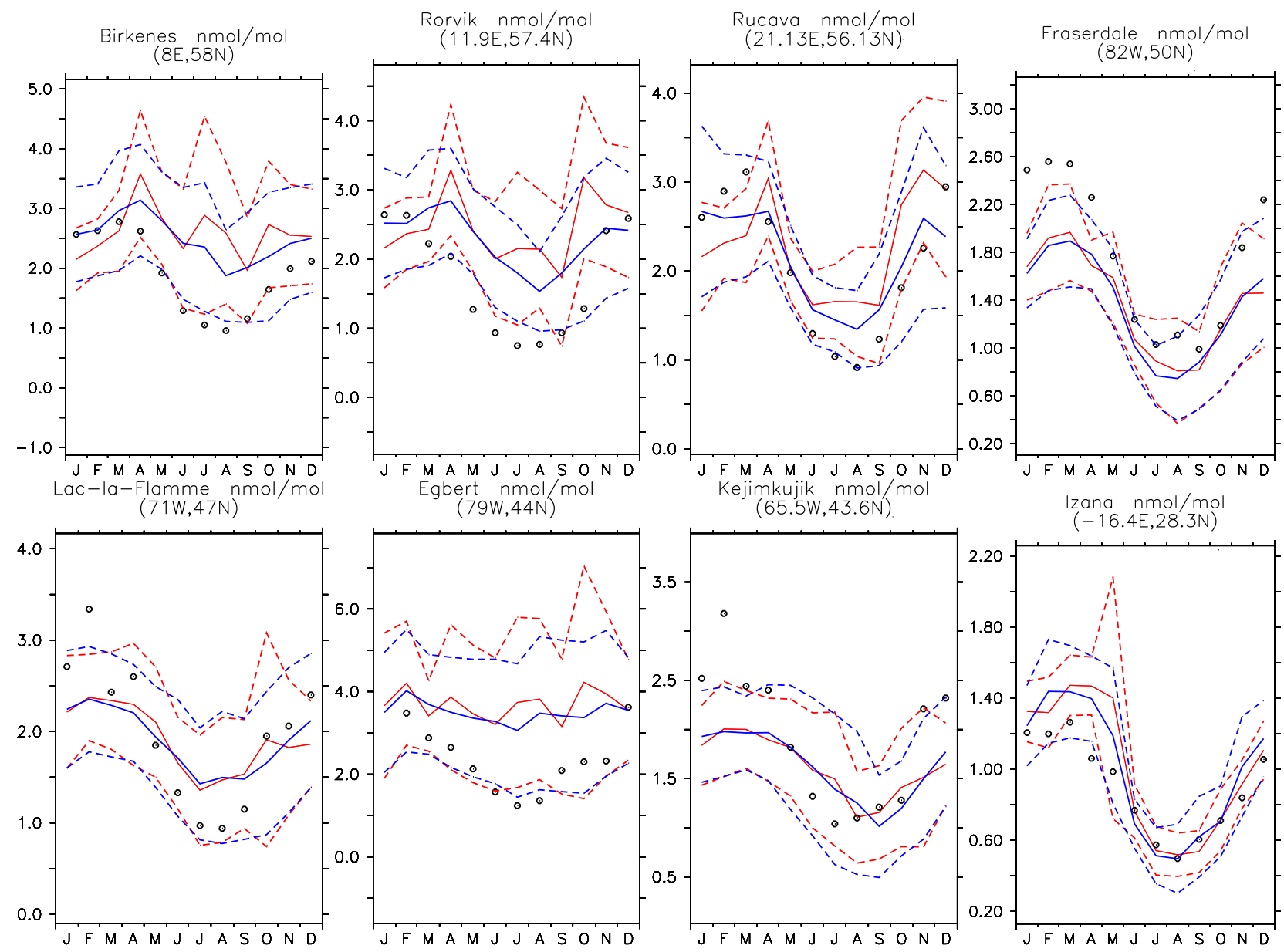

Fig. 12. Seasonal cycle (monthly averages) of $\mathrm{C}_{2} \mathrm{H}_{6}$ (in nmol/mol) for some selected locations at the surface (Solberg et al., 1996). Model: solid line; model standard deviation: dashed line; measurements: circles. The red and blue lines indicate results from simulation F1 and simulation S1, respectively. The stations are ordered by latitude.
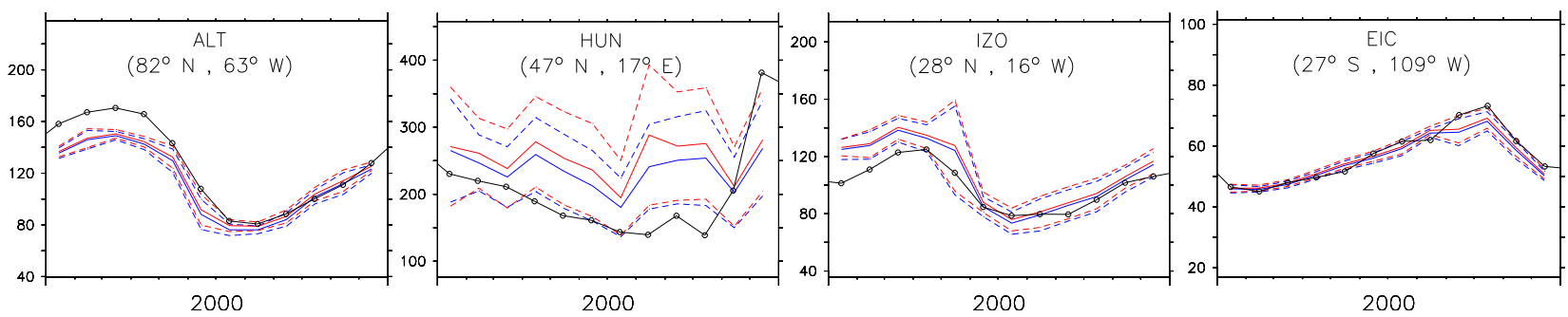

Fig. 13. Comparison of simulated and observed (black, Novelli et al., 1998) CO mixing ratios in nmol/mol (ordered by latitude). The simulated average is indicated by the red and blue lines, for simulation F1 and simulation S1 respectively. The corresponding simulated standard deviations w.r.t. time are represented by the dashed lines.

stability). Although some work in this direction has been performed for biomass burning (Freitas et al., 2006, 2007) already, more work on anthropogenic emissions is required. New emission (plume) models have to be applied and many more observations of "real world" emissions are required to further constrain the models.
Acknowledgements. The authors wish to acknowledge the suggestions by the editor B. Duncan and the two anonymous referee for improving the manuscript, P. Zimmermann and T. Butler for preparing the emissions files, H. Riede for comments, and M. Lawrence for valuable suggestions on the manuscript. The authors wish also to acknowledge the use of the Ferret program for analyses and graphics in this paper. Ferret is a product of NOAA's 
Pacific Marine Environmental Laboratory (information is available at http://www.ferret.noaa.gov).

The authors acknowledge for their strong support the European Commission, Airbus, CNRS-France, FZJ-Germany and the airlines (Lufthansa, Air France, Austrian and former Sabena who carry free of charge the MOZAIC instrumentation since 1994).

The service charges for this open access publication

have been covered by the Max Planck Society.

Edited by: B. N. Duncan

\section{References}

Atkinson, R.: Atmospheric chemistry of VOCs and $\mathrm{NO}_{\mathrm{x}}$, Atmos. Environ., 34, 2063-2101, 2000.

Bottenheim, J. W. and Shepherd, B. F.: $\mathrm{C}_{2}-\mathrm{C}_{6}$ hydrocarbon measurements at four rural locations across Canada, J. Geophys. Res., 29, 647-664, 1995.

Clarkson, T. S., Martin, R. J., and Rudolph, J.: Ethane and propane in the southern marine troposphere, Atmos. Environ., 31, 37633771, 1997.

Colarco, P. and Andreae, M.: Biomass burning in the tropics: Impact on atmospheric chemistry and biogeochemical cycles, J. Geophys. Res., 109, D06203, doi:10.1029/2003JD004248, 2004.

Cook, P., Savage, N. H., Turquety, S. et al.: Forest fire plumes over the North Atlantic: p-TOMCAT model simulations with aircragt and satellite measurements from the ITOP/ICARTT campaign, J. Geophys. Res., 112, D10S43, doi:10.1029/2006JD007563, 2007.

de Meij, A., Krol, M., Dentener, F., Vignati, E., Cuvelier, C., and Thunis, P.: The sensitivity of aerosol in Europe to two different emission inventories and temporal distribution of emissions, Atmos. Chem. Phys., 6, 4287-4309, 2006, http://www.atmos-chem-phys.net/6/4287/2006/.

Dimitroulopoulou, C. and ApSimon, H. M.: The influence of the photolysis rates on modelled ozone concentrations, Atmos. Environ., 33, 147-154, 1999.

Emmons, L. K., Hauglustaine, D.A., Müller, J. F., Carroll, M. A., Brasseur, G. P., Brunner, D., Staehelin, J., Thouret, V., and Marenco, A.: Data composites of airborne observations of tropospheric ozone and its precursors, J. Geophys. Res., 105, 2049720538, 2000.

Ferguson, S., Collins, R., Ruthford, J., and Fukuda, M.: Vertical distribution of nighttime smoke following a wildland biomass fire in boreal Alaska, J. Geophys. Res., 108(D23), 4743, doi:10.1029/2002JD003324, 2003.

Freitas, S. R., Longo, K., and Andreae, M.: Impact of including the plume rise of vegetation fires in numerical simulations of associated atmospheric pollutants, Geophys. Res. Lett., 33, L17808, doi:10.1029/2006GL026608, 2006.

Freitas, S. R., Longo, K. M., Chatfield, R., Latham, D., Silva Dias, M. A. F., Andreae, M. O., Prins, E., Santos, J. C., Gielow, R., and Carvalho Jr., J. A.: Including the sub-grid scale plume rise of vegetation fires in low resolution atmospheric transport models, Atmos. Chem. Phys., 7, 3385-3398, 2007, http://www.atmos-chem-phys.net/7/3385/2007/.

Friedrich, R., Heidegger, A., and Kudermann, F.: Development of an emission calculation module as a part of a model network for regional atmospheric modelling, in: Proceedings of the EUROTRAC Symposium 1998: Garmisch-Partenkirchen, edited by WIT Press, Boston, S., 2000.

Fromm, Bevilaqua, R., Servranckx, R., Rosen, J., Thayer, J., Herman, J., and Larko, D.: Pyro-cumulonimbus injection of smoke to the stratosphere: Observation and impact of a super blowup in northwestern Canada on 3-4 August 1998, J. Geophys. Res., 110, D08205, doi:10.1029/2004JD005350, 2005.

Fromm, M., Alfred, J., Hoppel, K., Hornstein, J., Bevilaqua, R., Shettle, E., Servranckx, R., Z, L., and Stocks, S.: Observation of boreal forest fire smoke in the stratosphere by POAM III, SAGE III and lidar in 1998, Geophys. Res. Lett., 27, 1407-1410, 2000.

Generoso, S., Bey, I., Attie, J. L., and Breon, F. M.: A satelliteand model-based assessment of the 2003 Russian fires: inpact on the Artic region., J. Geophys. Res., 112, D15302, doi:10.1029/2006JD008344, 2007.

Goldstein, A. H., Wofsy, S. C., and Spivakovsky, C. M.: Seasonal variation of nonmethane hydrocarbons in rural New England: Constraints on $\mathrm{OH}$ concentrations in northern midlatitudes, J. Geophys. Res., 100, 21023-21033, 1995.

Greenberg, J. P., Helmig, D., and Zimmerman, P. R.: Seasonal measurements of nonmethane hydrocarbons and carbon monoxide at the Mauna Loa Observatory during the Mauna Loa Observatory Photochemitry Experiment 2, J. Geophys. Res., 101, 1458114598, 1996.

Haas-Laursen, D. and Hartley, D.: Consistent sampling methods for comparing models to $\mathrm{CO}_{2}$ flask data, J. Geophys. Res., 102, 19059-19071, 1997.

Hodzic, A., Madronich, S., Bohn, B., Massie, S., Menut, L., and Wiedinmyer, C.: Wildfire particulate matter in Europe during summer 2003: meso-scale modeling of smoke emissions, transport and radiative effects, Atmos. Chem. Phys., 7, 4043-4064, 2007, http://www.atmos-chem-phys.net/7/4043/2007/.

Holtslag, A. A. M. and Boville, B. A.: Local versus nonlocal boundary-layer diffusion in a global climate model, J. Climate, 6, 1825-1841, 1993.

Holtslag,A. A. M., de Bruijn,E. I. F., and Pan, H.-L.: A high resolution air mass transformation model for short-range weather forecasting, Mon. Weather Rev., 118, 1561-1575, 1990.

Houweling, S., Dentener, F., and Lelieveld, J.: The impact of nonmethane hydrocarbon compounds on tropospheric photochemistry, J. Geophys. Res., 103, 10673-10696, 1998.

Jacob, D., Field, B., Jin, E., Bey, I., Li, Q., Logan, J., and Yantosca, R.: Atmospheric budget of acetone, J. Geophys. Res., 107, 4100, doi:10.1029/2001JD000694, 2002.

Jeuken, A., Siegmund, P., Heijboer, L., Feichter, J., and Bengtsson, L.: On the potential assimilating meteorological analyses in a global model for the purpose of model validation, J. Geophys. Res., 101, 16939-16950, 1996.

Jöckel, P., Sander, R., Kerkweg, A., Tost, H., and Lelieveld, J.: Technical Note: The Modular Earth Submodel System (MESSy) - a new approach towards Earth System Modeling, Atmos. Chem. Phys., 5, 433-444, 2005,

http://www.atmos-chem-phys.net/5/433/2005/.

Jöckel, P., Tost, H., Pozzer, A., Brhl, C., Buchholz, J., Ganzeveld, L., Hoor, P., Kerkweg, A., Lawrence, M. G., Sander, R., Steil, B., Stiller, G., Tanarhte, M., Taraborrelli, D., van Aardenne, J., and Lelieveld, J.: The atmospheric chemistry general circulation 
model ECHAM5/MESSy1: consistent simulation of ozone from the surface to the mesosphere, Atmos. Chem. Phys., 6, 50675104, 2006, http://www.atmos-chem-phys.net/6/5067/2006/.

Jost, H.-J., Drdla, K., Stohl, A., et al.: In-situ observations of midlatitude forest fire plumes deep in the stratosphere, Geophys. Res. Lett., 31, L11101, doi:10.1029/2003GL019253, 2004.

Kerkweg, A., Buchholz, J., Ganzeveld, L., Pozzer, A., Tost, H., and Jöckel, P.: Technical Note: An implementation of the dry removal processes DRY DEPosition and SEDImentation in the Modular Earth Submodel System (MESSy), Atmos. Chem. Phys., 6, 4617-4632, 2006a, http://www.atmos-chem-phys.net/6/4617/2006/.

Kerkweg, A., Sander, R., Tost, H., and Jckel, P.: Technical note: Implementation of prescribed (OFFLEM), calculated (ONLEM), and pseudo-emissions (TNUDGE) of chemical species in the Modular Earth Submodel System (MESSy), Atmos. Chem. Phys., 6, 3603-3609, 2006b,

http://www.atmos-chem-phys.net/6/3603/2006/.

Labonne, M., Breon, F. M., and Chevallier, F.: Injiection height of biomass burning aerosol as seen from a spaceborne lidar, Geophys. Res. Lett., 34, L11806, doi:10.1029/2007GR029311, 2007.

Langmann, B., Duncan, B., Textor, C., Trentmann, J., and van der Werf, G.: Vegetation fire emissions and their impact on air pollution and climate, Atmos. Environ., 43, 107-116, 2009.

Lelieveld, J., Peters, W., Dentener, F., and Krol, M.: Stability of tropospheric hydroxyl chemistry, J. Geophys. Res., 107, 4715, doi:10.1029/2002JD002272, 2002.

Lelieveld, J., Brühl, C., Steil, B., Crutzen, P., Fischer, H., Giorgietta, M., Hoor, P., Milz, M., Sausen, R., Stiller, G., and Tost, H.: Stratospheric dryness, Atmos. Chem. Phys., 7, 1313-1332, 2007 , http://www.atmos-chem-phys.net/7/1313/2007/.

Lindskog, A. and Moldanová, J.: The Influence of the Origin, Season and Time of the day on the Distribution of Individual NMHC Measured at Rörvik, Sweden, Atmos. Environ., 28, 2383-2398, 1994.

Logan, J. A.: An analysis of ozone-sonde data for the troposphere: Recommendations for testing 3-D models and development of a gridded climatology for tropospheric ozone, J. Geophys. Res., 104, 16115-16149, 1999.

Logan, J. A.: Tropospheric ozone: Seasonal behavior, trends, and anthropogenic influence, J. Geophys. Res., 90, 10463-10482, 1985.

Logan, J. A., Prather, M. J., Wofsy, S. C., and McElroy, M. B.: Tropospheric chemistry: A global perspective, J. Geophys. Res., 86, 7210-7254, 1981.

Luderer, G., Trentmann, J., Winterrath, T., Textor, C., Herzog, M., Graf, H.-F., and Andreae, M.: Modeling of biomass smoke injection into lower stratosphere by a large forest fire: Sensitivity studies, Atmos. Chem. Phys., 6, 5261-5277, 2006, http://www.atmos-chem-phys.net/6/5261/2006/.

Matichuk, R., Cloarco, P., Smith, J., and Toon, O.: Modeling the transport and optical properties of smoke aerosol form African savanna fires during the Southern African Regional Science Initiative campaign (SAFARI 2000), J. Geophys. Res., 112, D08203, doi:10.1029/2006JD007528, 2007.

Novelli, P. C., Masarie, K. A., and Lang, P. M.: Distribution and recent changes of carbon monoxide in the lower troposphere, J. Geophys. Res., 103, 19015-19033, 1998.

Pfister, G., Hess, P., Emmons, L., Lamarque, J. F., Edwards, D., Petron, G., Gille, J., and Sachse, G.: Quantifying CO emissions from the 2004 Alaskan wildfires using MOPITT CO data, Geophys. Res. Lett., 32, L11809, doi:10.1029/2005GL022995, 2005.

Pozzer, A., Jöckel, P., Tost, H., Sander, R., Ganzeveld, L., Kerkweg, A., and Lelieveld, J.: Simulating organic species with the global atmospheric chemistry general circulation model ECHAM5/MESSy1: a comparison of model results with observations, Atmos. Chem. Phys., 7, 2527-2550, 2007, http://www.atmos-chem-phys.net/7/2527/2007/.

Pregger, T. and Friedrich, R.: Effective pollutant emission heights for atmospheric transport modelling based on realworld information, Environmental Pollution, 157(2), 552-560, doi:10.1016/j.envpol.2008.09.027, 2009.

Price, C. and Rind, D.: A simple lightning parameterization for calculating global lightning distributions, J. Geophys. Res., 97, 9919-9933, 1992.

Roeckner, E., Brokopf, R., Esch, M., Giorgetta, M., Hagemann, S., Kornblueh, L., Manzini, E., Schlese, U., and Schulzweida, U.: Sensitivity of simulated climate to horizontal and vertical resolution in the ECHAM5 atmosphere model, J. Clim., 19, 37713791, 2006.

Rudolph, J., Khedim, A., and Wagenbach, E.: The Seasonal Variation of Light Non-methane Hydrocarbons in the Antarctic Troposphere, J. Geophys. Res., 94, 13039-13044, 1989.

Rudolph, J. and Johnen, F. J.: Measurements of light atmopsheric hydrocarbons over the Atlantic in regions of low biological activity, J. Geophys. Res., 95, 20583-20591, 1990.

Schmitt, A. and Brunner, B.: Emissions from aviation and their development over time. In Pollutants from air traffic - results of atmospheric research 1992-1997. Final Report on the BMBF Verbundprogramm "Schadstoffe in der Luftfahrt", Tech. report, DLR - Mitteilung 97-04, pages 1-301, 1997.

Sander, R., Kerkweg, A., Jöckel, P., and Lelieveld, J.: Technical note: The new comprehensive atmospheric chemistry module MECCA, Atmos. Chem. Phys., 5, 445-450, 2005, http://www.atmos-chem-phys.net/5/445/2005/.

Seinfeld, J. H. and Pandis, S.: Atmospheric Chemistry and Physics: From Air Pollution to Climate Change, Wiley-Interscience, 204 231, 1997.

Simpson, D., Fagerli, H., Jonson, J., Tsyro, S., Wind, P., and Tuovinen, J. P.: Unified EMEP Model Description., Tech. rep., Norwegian Meteorological Institute, 2003.

Solberg, S., Dye, C., Schmidbauer, N., Herzog, A., and Gehrig, R.: Carbonyls and nonmethane hydrocarbons at rural European sites from the Mediterranean to the Arctic, J. Atmos. Chem., 25, 3366, 1996.

Taylor, K. E.: Summarizing multiple aspects of model performance in a single diagram, J. Geophys. Res., 106, 7183-7192, 2001

Talbot, R. W., Bradshaw, J. D., Sandholm, S. T., Smyth, S., Blake, D. R., Blake, N. R., Sachse, G. W., Collins, J. E., Heikes, B. G., Anderson, B. E., Gregory, G. L., Singh, H. B., Lefer, B. L., and Bachmeier, A. S.: Chemical characteristics of continental outflow over the tropical South Atlantic Ocean from Brazil and Africa, J. Geophys. Res., 101, 24187-24202, 1996.

Thompson, A.: The oxidizing capacity of the Earth's atmosphere: Probable past and future changes, Science, 256, 1157-1165, 
1992.

Thompson, A. M., Witte, J. C., McPeters, R. D., Oltmans, S. J., Schmidlin, F. J., Logan, J. A., Fujiwara, M., Kirchhoff, V. W. J. H., Psny, F., Coetzee, G. J. R., Hoegger, B., Kawakami, S., Ogawa, T., Johnson, B. J., Vömel, H., and Labow, G.: Southern Hemisphere Aditional Ozonesondes SHADOZ 1998-2000 tropical ozone climatology: Comparison with Total Ozone Mapping Spectrometer (TOMS) and ground-based measurements, J. Geophys. Res., 108(D2), 8238, doi:10.1029/2001JD000967, 2003.

Tost, H., Jöckel, P., Kerkweg, A., Sander, R., and Lelieveld, J.: Technical Note: A new comprehensive SCAVenging submodel for global atmospheric chemistry modelling, Atmos. Chem. Phys., 6, 565-574, 2006, http://www.atmos-chem-phys.net/6/565/2006/.

Troen, I. and Mahrt, L.: A simple model of the atmospheric boundary layer; sensitivity to surface evaporation, Bound.-Lay. Meteorol., 37, 129-148, 1986.

Turquety, S., Logan, J., Jacob, D., Hudman, R., Leung, F., Heald, C., Yantosca, R., Wu, S., Emmons, L., Edwards, D., and Sachse, G.: Inventory of boreal fire emissions for North America in 2004: Importance of peat burning and pyroconvective injection, J. Geophys. Res., 112, D12S03, doi:10.1029/2006JD007281, 2007. van Aardenne, J., Dentener, F., Olivier, J., Peters, J., and Ganzeveld, L.: The EDGAR 3.2 Fast Track 2000 dataset (32FT2000), http://www.mnp.nl/edgar/model/v32ft2000edgar/ docv32ft2000/, 2005.

Van der Werf, G. R., Randerson, J. T., Collatz, G. J., Giglio, L., Kasibhatla, P. S., Avelino, A., Olsen, S. C., and Kasischke, E. S.: Continental-scale partitioning of fire emissions during the 19972001 El Nino/La Nina period, Science, 303, 73-76, 2004.

RMIB \& NASA-WFF. World Ozone and Ultraviolet Radiation Data Centre (WOUDC). Retrieved October 20, from http://www. woudc.org, 2009.

Zbinden, R. M., Cammas, J.-P., Thouret, V., Nédélec, P., Karcher, F., and Simon, P.: Mid-latitude tropospheric ozone columns from the MOZAIC program: climatology and interannual variability, Atmos. Chem. Phys., 6, 1053-1073, 2006, http://www.atmos-chem-phys.net/6/1053/2006/. 